\title{
REVIEW
}

UDC 577.352.5

doi: https://doi.org/10.15407/ubj93.06.005

\section{BIOCHEMICAL AND MOLECULAR-PHYSIOLOGICAL ASPECTS OF THE NITRIC OXIDE ACTION IN THE UTERA}

\author{
H. V. DANYLOVYCH, Yu. V. DANYLOVYCH \\ Palladin Institute of Biochemistry, National Academy of Sciences of Ukraine, Kyiv; \\ e-mail: danylovych@biochem.kiev.ua
}

Received: 18 May 2021; Accepted: 12 November 2021

The sources of the nitric oxide (NO) formation in the uterus and the dynamics of changes in its content in different periods of organ functioning in human and animals are analyzed. The biochemical mechanisms of $N O$ action on the myometrium contractile activity, the significance of $N O$ in the physiological processes during pregnancy and labor, the importance of mitochondria as a reliable NO source in the smooth muscle and the possible ways of $\mathrm{NO}$ influence on $\mathrm{Ca}^{2+}$ transport and bioenergetic processes in mitochondria are considered. The authors' data concerning ionic and membrane mechanisms of NO action on $\mathrm{Ca}^{2+}$-homeostasis of uterine myocytes, identification of nitric oxide in uterine smooth muscle mitochondria, biochemical characteristics of the $\mathrm{NO}$-synthase reaction and the possible role of $\mathrm{NO}$ in the regulation of $\mathrm{Ca}^{2+}$ transport in these subcellular structures and in the electron transport chain functioning are presented and discussed.

Ke ywords: uterus, pregnancy, nitric oxide, mitochondria, calcium.

$\mathrm{N}$ itric oxide (NO) is a universal signaling and regulatory molecule in cells. An important manifestation of its biological activity is the control of the contractile function of smooth muscles, which largely determines the normal functioning of internal organs, including the genitourinary system [1-5].

The results of experimental work over many years allow us to make assumptions about the significance of nitric oxide in processes that prevent the contractile response to stretching of the uterine wall due to embryonic growth and reduce the sensitivity of the myometrium to uteroconstrictor agents, which is especially important in the normal course of pregnancy. Both NO production and sensitivity to it decrease at the end of pregnancy and precede the beginning of labor [6-10]. Nitric oxide donors cause relaxation of the myometrium of both non-pregnant women and those with different stages of pregnancy [11]. A corresponding decrease in the contractile ability of uterine smooth muscle cells is also shown in some animal species, including rats and primates, in different periods of functional activity of the organ $[6-8,12,13]$. However, the biochemical mechanisms whereby nitric oxide controls the contractile function of the myometrium are currently poorly understood.

Changes in the cytosolic concentration of $\mathrm{Ca}^{2+}$ underlie the control of smooth muscle contractile activity, and $\mathrm{Ca}^{2+}$-transport systems of subcellular structures, in particular mitochondria, are a target for substances that modulate the contractile function of myocytes [14]. The ability of NO to relax the myometrium determines the interest in studying the biochemical patterns of its effect on $\mathrm{Ca}^{2+}$-homeostasis in myometrial cells.

Sources of NO in the uterus can be its endometrial tissue [15-18] and vascular endothelium [19-21]. Nerve endings that contain neuronal NO-synthase and provide nitrergic innervation of the uterus have

(C) 2021 Danylovych H.V., Danylovych Yu.V. This is an open-access article distributed under the terms of the Creative Commons Attribution License, which permits unrestricted use, distribution, and reproduction in any medium, provided the original author and source are credited. 
also been identified [22]. A potential source of $\mathrm{NO}$ in the myometrium, according to information reported about other tissues, can be mitochondria [23-28].

The study of the pathways of formation and functional activity of nitric oxide in uterine tissues is an urgent scientific problem due to the relatively small number of scientific publications compared to the cardiovascular system. The sources of nitric oxide in the uterus, the patterns of formation in the organ' vessels and endometrium, the significance of $\mathrm{NO}$ in the regulation of fetoplacental circulation are poorly studied. The biochemical mechanisms of nitric oxide action on $\mathrm{Ca}^{2+}$-homeostasis in the myometrium and, accordingly, the ways of its relaxing effect on uterine smooth muscle remain unclear. There is no information about NO formation, catalytic and kinetic properties of the smooth muscle mitochondria NO-synthase system, in particular in myometrial cells. Research efforts in this direction will provide a better understanding of the regulation of contractile activity of the uterus in different periods of its functioning and thus enable the development of a new generation of tocolytic drugs based on NO donors and precursors and drugs targeted nitric oxide synthesis in the uterus. These investigations have a vital medical and social significance because it is directly related to the improvement of the reproductive situation in Ukraine. The present review summarizes current knowledge on the mentioned above issues and analyses the results of our research.

\section{Nitric oxide biosynthesis}

In recent decades, nitric oxide attracts great interest due to its regulatory role in intracellular processes and intercellular interactions. Nitric oxide has become one of the most studied molecules in the biomedical sciences since its discovery (the early 1980s) by R. Farchgot and J. Zavadsky "as an endothelial relaxation factor (EDRF)", and the appearance of the works of L. Ignarro and F. Murad (1986-1988), who identified EDRF as NO. NO was named the "molecule of the year" in 1992. In 1998 R. Farchgot, L. Ignarro and F. Murad received the Nobel Prize in Physiology and Medicine [3, 29]. Since then, the range of known functions performed by nitric oxide has expanded significantly. $\mathrm{NO}$ as an intracellular and intercellular messenger is involved in the regulation of numerous metabolic reactions and physiological processes, which contributes to the organism's normal functioning. Nitric oxide controls the cardiovascular system, hemostasis, neurotrans- mission, immunomodulation and antimicrobial protection, affects the secretion of hormones, etc [1-5].

Nitric oxide is a low molecular weight, amphiphilic, free radical molecule. NO in biosystems has a relatively short lifetime (up to $5 \mathrm{~s}$ depending on the microenvironment) and can migrate short distances from the generation sites, which is determined by the rate of oxidation [1, 30-33]. This defines the functional significance of $\mathrm{NO}$ as a paracrine regulator and its local action in subcellular compartments. According to the concept of "nitric oxide cycle" in animal cells, there are two main ways of nitric oxide formation: NO-synthase and nitrite/nitrate reductase [34].

NO synthesis in the cell under normoxia is provided by a family of NO-synthase isoforms (NOS, E.C. 1.14.13.39), which in the presence of NADPH as an electron source and $\mathrm{O}_{2}$ carry out five-electron two-stage oxidation of the guanidine group of L-arginine to form NO and L-citrulline [1, 30]. The total equation of reaction (1), which is NOS catalyzed, is as follows:

$\mathrm{L}$-arginine $+1.5 \mathrm{NADPH}+1.5 \mathrm{H}^{+}+2 \mathrm{O}_{2} \rightarrow$
$\rightarrow$ L-citrulline $+\mathrm{NO}+1.5 \mathrm{NADP}^{+}+2 \mathrm{H}_{2} \mathrm{O}$

The NOS enzyme exists as a dimer consisting of two identical subunits, structurally and functionally divided into two main domains: C-terminal reductase and $\mathrm{N}$-terminal oxygenase. The reductase domain contains NADPH, FAD, and FMN binding sites; the oxygenase domain binds heme, cofactor BH4 (6(R)-5,6,7,8-tetrahydrobiopterin) and substrate L-arginine. Between these two regions, there is calmodulin-binding domain. NO synthase exhibits oxidase activity under certain conditions, in particular in the absence of cofactors and substrate, which causes the separation of reductase and oxygenase domains and disruption of electron transport between them, resulting in the formation of superoxide anion $\left(\mathrm{O}_{2}^{-}\right)$. Further, NO redox forms with different nitrogen oxidation states as well as hydrogen peroxide $\left(\mathrm{H}_{2} \mathrm{O}_{2}\right)$ are formed [31]. Conversion of $\mathrm{NO}$ in aerated aqueous solutions under physiological conditions leads to the appearance of nitrite-anion $\left(\mathrm{NO}_{2}{ }^{-}\right)$and nitrate-anion $\left(\mathrm{NO}_{3}^{-}\right)$[3, 34].

There are 3 isoforms of NOS, which differ in structure and function. Constitutively expressed $\mathrm{Ca}^{2+}$-dependent enzymes are endothelial NOS (eNOS/NOS III) and neuronal NOS (nNOS/NOS I). The activity of inducible NOS (iNOS/NOS II) does not depend on intracellular $\mathrm{Ca}^{2+}$, as calmodulin is strongly bound at the corresponding site owing to 
the specific amino acid sequence [30, 33, 35-37]. This isoform is not expressed in most cells under normal conditions, but its synthesis is induced by proinflammatory cytokines (TNF- $\alpha$, INF- $\gamma$, IL-1 $\beta$ ), bacterial lipopolysaccharides, $\gamma$-irradiation [37-39] under the control of signaling pathways, associated with NF-kB and JAK/STATs [2, 11, 23, 32, 35, 39-43].

$n N O S$ is expressed in central and peripheral neurons and in the epithelial cells of the lungs, skeletal muscle, uterus, stomach, kidneys, pancreas $[35,41]$. There are several splice variants of nNOS $[30,44,45]$. nNOS $\alpha$ and $n N O S \mu$, most common in tissues, contain a PDZ-domain at the $\mathrm{N}$-terminus that can interact with PDZ-motifs of other proteins, which determines the subcellular localization and activity of the enzyme [46-48]. The splice variant $n N O S \mu$ is expressed in the muscles. It interacts via PDZ-domain with the C-terminal region of plasma membrane $\mathrm{Ca}^{2+}$-transport ATPase (PMCA), namely isoform $4 \mathrm{~b}$, which is contained in smooth muscle. In this case, the decrease in subplasmallemal $\mathrm{Ca}^{2+}$ concentration acts as a negative regulator of NO synthesis. The interaction of nNOS with the cytosolic site of adrenergic and glutamatergic receptors [1, 30, 49, $50], \alpha$-syntrophin-dystroglycan complex of skeletal muscle sarcolemma, phosphofructokinase, etc. is also shown [1, 47, 49]. In cardiomyocytes, nNOS can bind to the ryanodine receptor and xanthine oxidase on the surface of the sarcoplasmic reticulum [1].

The most important functions of nNOS include modulation of synapse plasticity in the central nervous system, central regulation of blood pressure, maintenance of smooth muscle tone of internal organs, in particular by generating NO in nitrergic nerve endings, control of blood supply to skeletal muscle fibers [35, 38, 44, 49, 51].

eNOS, first identified in endothelial cells, controls blood pressure and has vasoprotective, hemostatic and antiatherosclerotic effects. This isoform is found in lung and tracheal tissues, cardiomyocytes, platelets, brain neurons, syncytio-trophoblasts and renal epithelial cells [33, 41]. eNOS expression is controlled by a number of transcription factors, including HIF, NF- $\kappa B$, KLF2 [36, 41, 52]. Its content increases under hypoxia, an increase in shear stress on the vascular wall (increase in blood pressure), as well as in postischemic conditions. This isoform is membrane-bound, localized in the caveolae, but also found in the Golgi apparatus and the outer mitochondrial membrane [2, 53, 54]. eNOS association with caveolae is provided by acylation [30, 36, 41, 44, 55]. Interaction with the caveolin, a scaffolding protein of caveolae, inhibits the activity of eNOS, sterically blocking its interaction with calmodulin. Activation of the enzyme is provided by phosphorylation of the residue Ser-1177 and dephosphorylation of Thr-495 [2, 30, 35, 41, 49]. This phosphorylation is triggered by insulin, vascular endothelial growth factor, acetylcholine, bradykinin, estrogens, excessive endothelial pressure in hypertension, etc. [1-3, 32, 35, 49, 53] and performed by a number of kinases: Akt/PKB, PKA, PKG, AMPK, $\mathrm{Ca}^{2+}-\mathrm{CaMK}$ II and others [2, 30, 33, 35, 56, 57].

NO generated by eNOS regulates the tone and permeability of blood vessels, reduces aggregation and adhesion of platelets, participates in the functioning of cardiomyocytes, nervous and endocrine systems etc. [1-3, 32, 41, 58, 59].

iNOS, first detected in macrophages, was also identified in lymphocytes, neutrophils, eosinophils, uterine tissues. It is a soluble cytosolic protein who generates NO in large quantities, which has a cytotoxic effect on microorganisms and tumor cells [35, $38,41]$. Due to the high affinity for protein-bound iron, NO effectively interacts with iron-sulfur clusters of complexes of the mitochondria electron transport chain, cis-aconitase and ribonucleotide reductase, causing inhibition of these key bioenergetic and proliferation enzymes of the target cells [38, 49]. Nitric oxide produced by macrophages at very high concentrations also causes single-strand breaks and DNA fragmentation [35, 38, 58].

Other pathways to generate nitric oxide. The formation of nitrogen species from ammonia has been shown in nerve, liver tissues and lymphocytes where oxidation of $\mathrm{NH}_{4}^{+}$, with the participation of reactive oxygen species and hydroxylamine as the intermediate, occur $[60,61]$.

Nitrite-anion $\left(\mathrm{NO}_{2}^{-}\right)$and nitrate-anion $\left(\mathrm{NO}_{3}^{-}\right)$ are considered stable metabolites of $\mathrm{NO}[3,33,62]$. Nitric oxide synthesized by eNOS is particularly intensively oxidized to nitrites in the presence of the metalloenzyme ceruloplasmin, and to nitrates in the presence of oxyhemoglobin. The possibility of converting $\mathrm{NO}_{2}^{-}$to $\mathrm{NO}$ is shown in many tissues. This process is triggered under hypoxia or acidosis in the presence of reduced forms of heme-containing proteins, which is characteristic of ischemic conditions [56, 63]. Hemoglobin (Hb) in deoxyform plays an important role in the reduction of $\mathrm{NO}_{2}^{-}$in the blood, because bound oxygen prevents the interac- 
tion with $\mathrm{NO}_{2}{ }^{-}$and its conversion into NO [23]. Deoxymyoglobin has nitrite reductase activity in the heart and skeletal muscle [33, 64-66]. $\mathrm{NO}_{2}^{-}$reduction also occurs in mitochondria and microsomes. Cytochrome c-oxidase exhibits nitrite reductase activity in mitochondria, and cytochrome P-450 in microsomes [33]. NOS and xanthine oxidase also have reductase activity under hypoxia [23, 62, 64, 67]. The existence of such mechanisms for the nitric oxide synthesis allowed to formulate the concept of the "nitric oxide cycle" (Fig. 1). In this case, NO synthesis with the participation of NOS and non-enzymatic oxidation of $\mathrm{NH}_{4}^{+}$provide an endogenous synthesis of $\mathrm{NO}, \mathrm{NO}_{2}^{-}$and $\mathrm{NO}_{3}{ }^{-}$in the presence of oxygen. These mechanisms are suppressed when the partial pressure of $\mathrm{O}_{2}$ falls under hypoxia caused by functional stress or disruption of blood supply to the tissue (ischemia). At the same time, oxygen deficiency activates the reductase component of the cycle [3, 64, 68].

Given the metabolic relationship of NO and $\mathrm{NO}_{2}^{-}$, in view of the existence of the "nitric oxide cycle", the study of the functional activity of nitrite anions is an important research task. Endogenous nitrite has been shown to regulate numerous physiological processes [68]. It is a relatively stable depot of bioactive NO. In hypoxia, when NOS function is decreased, the nitrite reduction can help maintain NO pool to facilitate NO signaling and regulation during hypoxia and the metabolic stress caused by hypoxia [67]. NO-dependent nitrite-induced processes include inhibition of mitochondrial respiration, posttranslational covalent modification of proteins, regulation of gene expression, hypoxic vasodilation,

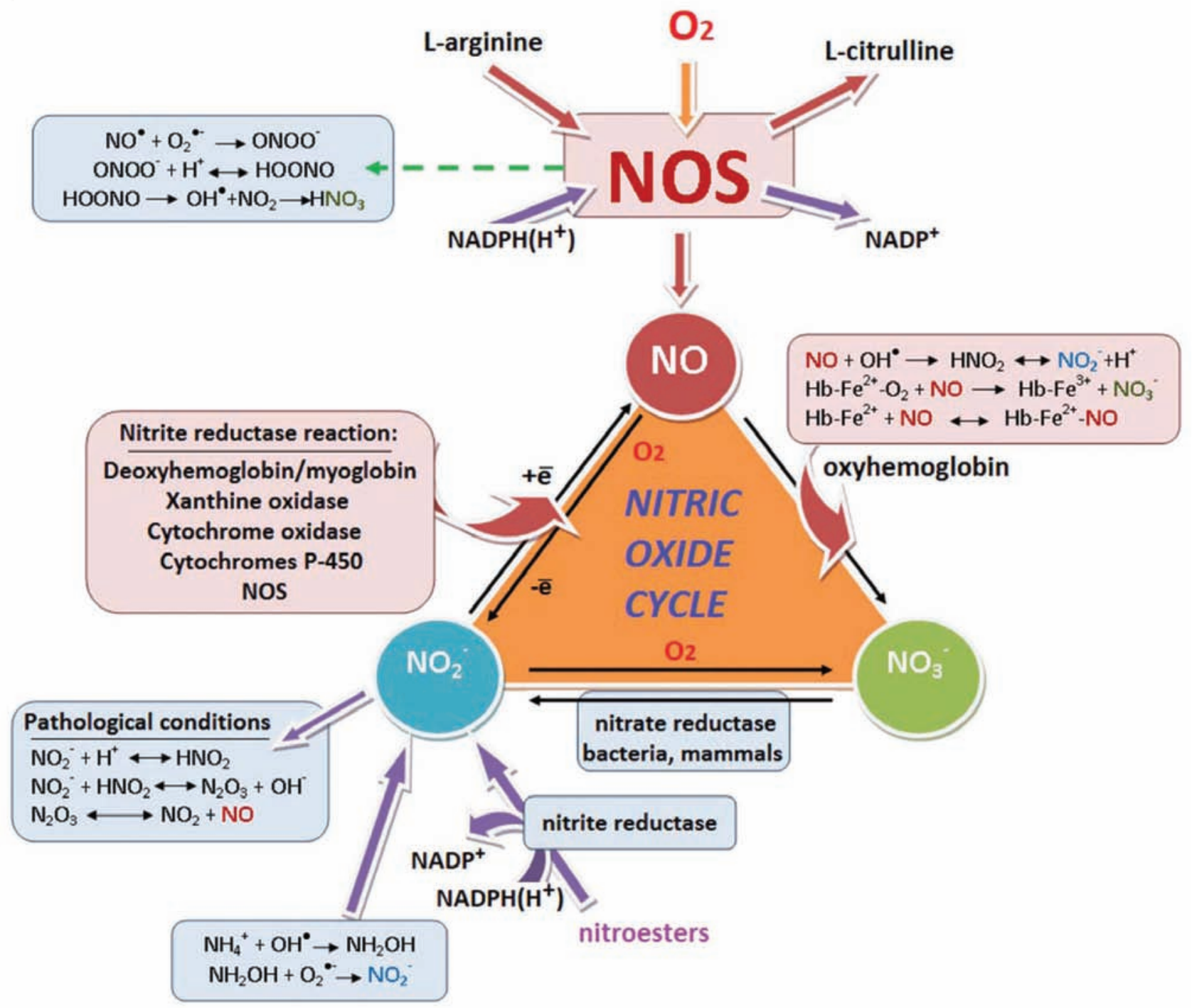

Fig. 1. Nitric oxide cycle 
angiogenesis, cytoprotection in ischemia/reperfusion, etc. [23, 63, 64]. The nitrite-anion is able to nitrate the tyrosine and tryptophan residues in proteins at $\mathrm{pH} \leq 6.0$ and is also catalyzed by peroxidases and hemoenzymes in the presence of nitrite and hydrogen peroxide. With the participation of methemoglobin and in the presence of $\mathrm{NO}, \mathrm{NO}_{2}^{-}$is converted into $\mathrm{N}_{2} \mathrm{O}_{3}-$ a potent nitrosylating agent $[31,64]$.

\section{Biochemical mechanisms that underlie the functional activity of NO}

The biological effects of nitric oxide due to the high reactivity are dependent on concentration and microenvironment, in particular the presence of reactive oxygen species. The threshold NO concentration, which determines the physiological effects, is about $1 \mu \mathrm{M}$ [69]. Local concentrations of $\mathrm{NO}$ in individual cell compartments can differ significantly from this value. NO has anti- or prooxidant effects depending on the concentration [31]. At low concentrations, nitric oxide interacts directly with biological targets (for example, lipoperoxides), which can lead to antioxidant effects [5]. It exhibits a prooxidant effect in high concentrations by forming reactive nitrogen species in the reaction of NO with molecular oxygen or reactive oxygen species [23]. The bioavailability of NO is substantially limited by the superoxide anion. These free radicals (NO' and $\mathrm{O}_{2}^{--}$) interact with the formation of peroxynitrite $\left(\mathrm{ONOO}^{-}\right)$through the diffusion-controlled reaction $[3,31]$. These conditions are created in the process of inflammation, the development of endothelial dysfunction on the background of increased production of pro-inflammatory cytokines [31]. The apparently paradoxical situation arises that the increase in iNOS expression and the resulting hyperproduction of NO is accompanied by a decrease in the physiological activity of nitric oxide, provided the simultaneous formation of reactive oxygen species and increased generation of peroxynitrite [32, 41, 43, 56].

The main mechanisms through which NO perform signaling and regulatory functions are [62, 70]:

(1) Activation of soluble guanylate cyclase (sGC) leads to the formation of cGMP, which, in turn, stimulates the PKG $[1,31,53,71]$. Signal termination in the key direction for the implementation of functional activity of nitric oxide NO/sGC/cGMP/ PKG is provided by the family of phosphodiesterases (PDE 5, 6, 9), which cleave cGMP [2-3, 72].

(2) S-nitrosylation: reactive nitrogen species $\left(\mathrm{NO}^{+}, \mathrm{NO}^{-}, \mathrm{N}_{2} \mathrm{O}_{3}, \mathrm{NO}_{2}\right.$ ) reversibly nitrosylate thiol groups of cysteines of target proteins. This process can occur by forming dinitrosyl complexes of nonheme iron (complexes of divalent iron with weakly bound anionic ligands, in the first place, thiol-containing), which are able to form coordination bonds with NO. Subsequent redistribution of electrons between two accepted NO molecules leads to the formation of nitrosonium cation $\left(\mathrm{NO}^{+}\right)-$a potent nitrosylating agent. There is a viewpoint that in the cardiovascular system, most NO effects are mediated through S-nitrosylation or transnitrosylation with the participation of low molecular weight nitrosothiols, such as S-nitrosoglutathione, and are cGMP-independent [31, 53, 55, 69, 73].

(3) Nitration by peroxynitrite of tyrosine and tryptophan residues in proteins that leads to the involvement in the signal transduction of mitogen-activated protein kinases, isoforms of PKC, transcription factor $\mathrm{NF}-\kappa \mathrm{B}$, etc. $[31,43,56,73]$. At moderate formation, peroxynitrite is considered a physiological regulator.

Nitric oxide affects numerous cellular processes. Depending on the concentration, it regulates gene transcription and mRNA translation (in particular, by altering the activity of transcription factors), causes and modulates posttranslational covalent protein modifications (such as nitrosylation, ADPribosylation), has cytostatic and cytotoxic properties $[31,69]$. By S-nitrosylation of functionally important cysteine residues of transport proteins, it provides a decrease in the concentration of $\mathrm{Ca}^{2+}$ in the cytoplasm of the smooth muscles cells of the internal organs and vessels [33]. In particular, the activity of potential-dependent $\mathrm{Ca}^{2+}$-channels, $\mathrm{Ca}^{2+}$-dependent $\mathrm{K}^{+}$-channels of the plasma membrane, PMCA and $\mathrm{Ca}^{2+}$-pump of the sarco(endo)plasmic reticulum (SERCA) are modulated by cGMP-dependent and/or independent manner [1, 33, 50].

Hyperproduction of NO by the cell, especially at high concentrations of reactive oxygen species, would lead to the formation of a range of highly reactive and dangerous nitrogen and oxygen species, so there must be effective mechanisms that inhibit the formation and reduce NO content. These include the processes of inhibition of NOS activity by reaction products, nitrosylation of membrane and cytosolic thiol groups, binding of NO to iron-sulfur centers and heme-containing proteins, its oxidation to $\mathrm{NO}_{2}^{-} / \mathrm{NO}_{3}^{-}$, etc. $[1,31,33,70]$. An increase in the level of cGMP in the cell under the NO action leads to the termination of the signal transduction by the 
$\mathrm{Ca}^{2+}$-phosphoinositide pathway. The reduction of eNOS activity is also achieved by phosphorylation, primarily the isoforms of PKC and MAPK (ERK extracellular responsive kinase) [31, 33, 38].

\section{Neurohumoral regulation of uterine contractile activity}

With the discovery of nitric oxide as a factor of relaxation of the vascular wall, studies of its effects in other types of smooth muscles began. The relevant interest in the myometrium is associated with its unique function in women, namely the fetal development during pregnancy and providing timely labor. According to statistical data, in the USA, 1 in 8 pregnancies end in preterm labor. Disproportionately high fetal mortality (about 20,000 annually) is observed among African Americans. In more than half of these cases, preterm births are spontaneous, and their causes are unclear [74].

Regulation of myometrial function during pregnancy, labor and the postnatal period is the central focus of reproductive science research. This complex problem involves elucidating cellular and molecular mechanisms of uterine smooth muscle contractile activity. The functioning of the myometrium, unlike other smooth muscles, is controlled mainly by hormones. Namely, steroid hormones progesterone and estrogens play a leading role in the uterine growth in the processes of increasing the embryo, maintaining its relative non-excitability during pregnancy (progesterone blockade), in preparation and during labor $[75,76]$. In addition to steroid hormones, there are a number of factors that regulate the contractile function of the myometrium. Oxytocin, certain prostaglandins (especially prostaglandin $\mathrm{F}_{2 \alpha}$ ), endothelin, platelet-activating factor contribute to uterine smooth muscle contraction, and corticotropin-releasing factor, prostacyclin (prostaglandin $\mathrm{I}_{2}$ ), nitric oxide, etc. relax it. It is well known that oxytocin generates the contraction of the myometrium during labor [77]. The uterus is a myogenic organ that can maintain contractile ability in the absence of direct neurohumoral effects. Although direct innervation of uterine myocytes has not been described, neurotransmitters, namely norepinephrine from sympathetic and acetylcholine from parasympathetic nerve fibers, are released between muscle bundles.

The blood vessels of the uterus are innervated by sympathetic, parasympathetic and sensory neurons. With parasympathetic stimulation, muscarinic cholinergic receptors are activated, resulting in vas- odilation. $\alpha$-adrenergic receptors are activated by sympathetic innervation, causing vasoconstriction $[14,78]$. During pregnancy, in the uterus blood vessels, the sympathetic neurotransmission increases, and parasympathetic, on the contrary, weakens [62].

The functional activity of the myometrium and its vessels is controlled by sensory neurons that secrete a number of neuromodulators: calcitonin generelated peptide (CGRP), substance P (SP), vasoactive intestinal polypeptide (VIP), neuropeptide Y (NPY) and neurokinins. By binding to the appropriate receptors on smooth muscle cells, CGRP has a relaxing effect on the vascular wall; circulating CGRP levels and sensitivity to its increase during pregnancy. It is assumed that SP stimulates myometrial contraction and play a significant role in cervical maturation. VIP has vasodilating properties and is also able to reduce the contractile activity of the myometrium. However, its main role is in anti-inflammatory action and regulation of the immune response during pregnancy [14].

In the vast majority of cases, the molecular basis for the regulation of the myometrium contractile activity under the action of the above compounds is the changes in the level of ionized $\mathrm{Ca}$ in the myoplasm. An increase in the concentration of $\mathrm{Ca}^{2+}$ is a central stage in biochemical and biophysical events between plasmalemma excitation (changes in membrane potential and/or ligand binding) and the development of muscle tissue contraction, particularly in the myometrium. These processes are called electro(pharmaco)mechanical coupling. As a result of the action potential propagation through syncytium in the smooth muscle [79], the plasma membrane is depolarized, and voltage-dependent $\mathrm{Ca}^{2+}$-channels are opened. The expression of its subunits in the myometrium is regulated by progesterone. Calcium ions, which entered in myoplasm by the concentration gradient, cause $\mathrm{Ca}^{2+}$-induced $\mathrm{Ca}^{2+}$ release (CICR) from the peripheral areas of the sarco(endo) plasmic reticulum through ryanodine-sensitive channels. In the case of pharmacomechanical coupling, the sequence of events between the binding of the corresponding ligand (biogenic amines, peptide hormones) and the increase in the concentration of $\mathrm{Ca}^{2+}$ in the myoplasm involves signaling through a system of heterotrimeric G-proteins to a key enzyme phospholipase $\mathrm{C}$ ( $\beta$-isoform). The activation of phospholipase $\mathrm{C}$ and the following hydrolysis of phosphatidylinositol-4,5-bisphosphate leads to the formation of secondary messengers inositol-1,4,5- 
trisphosphate ( $\mathrm{IP}_{3}$ ) and hydrophobic diacylglycerol $[14,80]$. Hydrophilic $\mathrm{IP}_{3}$ diffuses to the peripheral reticulum and causes the release of $\mathrm{Ca}^{2+}$ from the store by binding to the corresponding receptors $\left(\mathrm{IP}_{3}-\right.$ receptors, $\mathrm{IP}_{3}$-sensitive $\mathrm{Ca}^{2+}$-channel). This process is $\mathrm{Ca}^{2+}$-dependent. Diacylglycerol is able to modulate the $\mathrm{Ca}^{2+}$ signal by activating some isoforms of protein kinase C. Increased levels of $\mathrm{IP}_{3}$ in the myoplasm under the action of such agonists as acetylcholine or oxytocin reduces the concentration of $\mathrm{Ca}^{2+}$ in the lumen of the sarco(endo)plasmic reticulum that initiates the so-called "store-operated" or "capacitative" cation entry into the myoplasm [78, 81].

The increase in the myoplasm Ca ions concentration leads to the formation of the complex with a specific receptor protein calmodulin. The $\mathrm{Ca}^{2+}$-calmodulin complex subsequently activates myosin light chain kinase. This kinase directly phosphorylates regulatory light chains (mass about $20 \mathrm{kDa}$ ), resulting in the interaction of heavy chains with actin and subsequent activation of the contractile apparatus. The reverse dephosphorylation is carried out by myosin light chain phosphatase [14, 80, 82]. Dephosphorylation is further regulated by Rho-kinase, which inhibits phosphatase activity by phosphorylating the enzyme on tyrosine residues [83].

Decreased concentration of $\mathrm{Ca}^{2+}$ in myoplasm is a fundamental cause of smooth muscle relaxation, which is due to the processes of energy-dependent cation transport, involving ion pumps and exchangers of plasma membrane (PMCA and $\mathrm{NCX}-\mathrm{Na}^{+}$/ $\mathrm{Ca}^{2+}$-exchanger), sarco(endo)plasmic reticulum (thapsigargin-sensitive SERCA) and mitochondria $\left(\mathrm{Ca}^{2+}\right.$-uniporter) $[14,75,78]$. NCX works owing to the $\mathrm{Na}^{+}$gradient energy and, therefore, under the physiological conditions, ultimately depends on the $\mathrm{Na}^{+}, \mathrm{K}^{+}$-ATPase functioning $[14,81,84] . \mathrm{Ca}^{2+}$ uniporter accumulates $\mathrm{Ca}^{2+}$ in the matrix by electrophoretic mechanism due to a fairly high potential difference on the inner membrane of mitochondria, which can reach - $180 \mathrm{mV}$ (with a sign "“-” on the matrix) $[85,86]$.

Therefore, the increase in the myoplasm $\mathrm{Ca}^{2+}$ concentration is the first and main condition for the development of constriction. In connection with the intensive study of the value of nitric oxide or its derivatives (reactive nitrogen species) in the mechanisms of smooth muscle relaxation [3], some research teams are studying possible sources of nitric oxide in the uterus, as well as its functional activity, including the role of $\mathrm{NO}$ in $\mathrm{Ca}^{2+}$-dependent regulation of contraction-relaxation of the myometrium.

\section{Sources of the formation and physiological significance of nitric oxide in the uterus}

In the model of pregnant rats, it was shown that the uterus generates large amounts of nitrites and nitrates and can convert L-arginine to L-citrulline, which suggests the role of nitric oxide as a regulator of the organ functioning during pregnancy, including contractile activity [22]. NOS present in the uterus may also play a role in the fundamental physiological processes of vascular relaxation and inhibition of platelet aggregation necessary for the normal functioning of the endometrium [22, 87, 88]. Uterine vasodilation performs an essential role at the beginning of implantation and placentation.

NO can be produced by the endometrium, arterial endothelium, placental syncytiotrophoblasts and macrophages during different functional periods [11, $19,20,89]$. It is suggested that the endometrium is an important regulator of myometrial contractility, similar to the interaction between endothelium and smooth muscle syncytium [6-8]. We confirmed the possibility of NO production by the endometrium. Progesterone and acetylcholine were shown to stimulate this process, and the progesterone functional antagonist, uteroconstrictor peptide oxytocin, inhibits it (Fig. 2) [15, 16, 90].

Several isoforms of NO-synthase have been identified in uterine vessels and various parts of the endometrium. NOS-like protein was detected in blood vessels, glandular epithelium and endometrial stromal cells of non-pregnant women. eNOS was identified in uterine tissues of different gestational ages. However, the enzyme was not found in the uterine smooth muscle $[87,91]$. In the female endometrium, iNOS is localized in the glandular epithelium and decidual stromal cells. The latter may suggest that $\mathrm{NO}$ is involved in initiating and controling menstrual bleeding, possibly inhibiting platelet aggregation in the endometrium. Nitric oxide produced by the endometrium may inhibit the contractile activity of the myometrium of non-pregnant women [17].

Different NOS isoforms have also been identified in the uterus of animals. In particular, two isoforms of NOS were found in the glandular epithelium of the endometrium and uterine myometrium of pigs. iNOS and eNOS activities increase in the second half of pregnancy and decrease after delivery. 

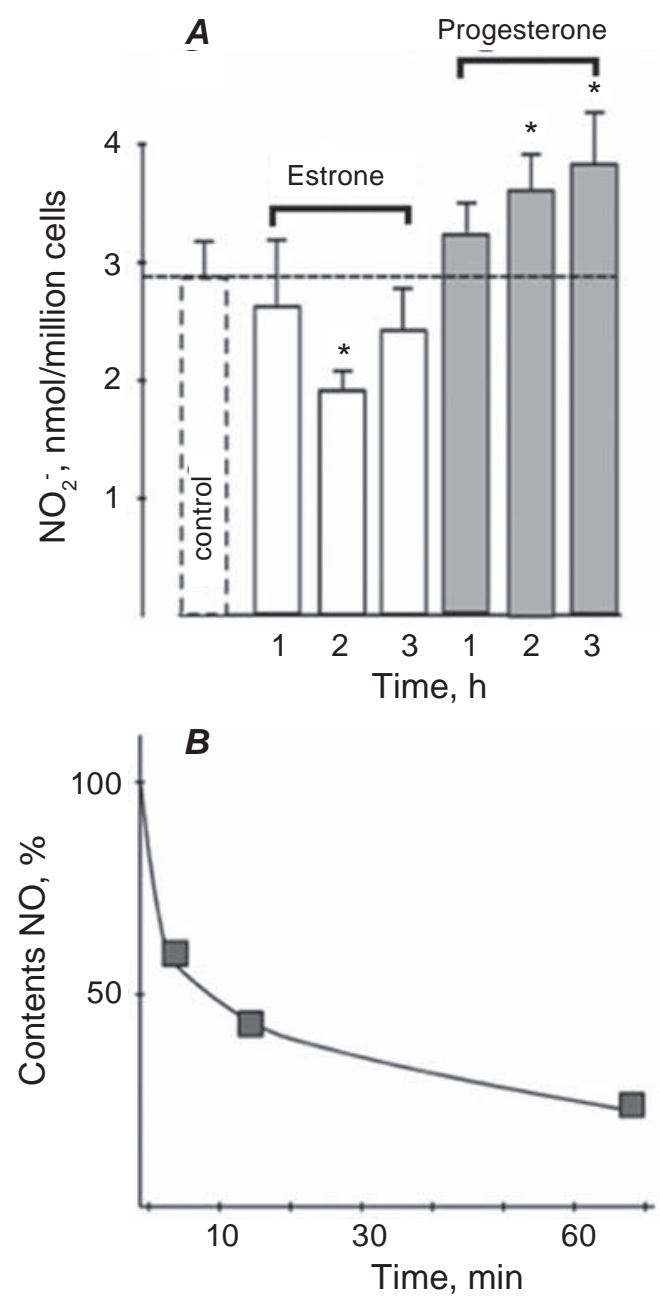

Fig. 2. Effect of $10 \mathrm{nM}$ estrone, progesterone (A) and $10 \mathrm{nM}$ oxytocin (B) on nitric oxide release by endometrial stromal cells into the extracellular environment. $\boldsymbol{A}$ - data are presented as mean \pm SEM, *changes are significant $v$ s. control, $P \leq 0.05, n=5$; $\boldsymbol{B}$ - these data represent typical experiments [16]

At the same time, the expression of sGC subunits increases in the glandular epithelium of the endometrium, its stromal cells and myometrium. This result indicates the involvement of the NO/cGMP signaling pathway during pregnancy [92].

NO synthesis studied in the uterus of pregnant rats at different stages of pregnancy and after labor, is also provided by eNOS and iNOS. The highest NOS content was on the $13^{\text {th }}$ day of pregnancy, with a subsequent decrease. The lowest expression was observed immediately after parturition [12]. It was shown that iNOS is the major isoform present in the reproductive organs of rats, and its regulation during pregnancy differs between the uterus, cervix and placenta. iNOS synthesis is high in the pregnant uterus and decreases just before parturition, which correlates with an increase in the oxytocin levels and expression of its receptors [91]. Opposite changes are observed in the cervix of rats. The level of this isoform during pregnancy is high in the placenta, but the decrease in its expression begins earlier than in the uterus. Based on the results of changes in the expression of different NOS isoforms, it was suggested that iNOS is responsible for large amounts of nitric oxide generated in the uterus and placenta during pregnancy, while eNOS is involved in vasodilation during this period [75]. It was confirmed by experiments in which the use of $\mathrm{N}^{\mathrm{G}}$-nitro-L-arginine methylester (L-NAME, an inhibitor of constitutive NOS, more selective for eNOS) in pregnant rats led to increased blood pressure and decreased content of NO metabolites in urine (nitrites and nitrates) in contrast to the administration of aminoguanidine (a more specific inhibitor of iNOS), which reduces the production of $\mathrm{NO}$ in urine without affecting blood pressure [75, 88, 93]. The expression and regulation of NOS are influenced by progesterone [75]. The negative effect of NOS inhibitors on pregnancy has been demonstrated. Inhibition of NOS by the LNAME is observed in the initiation of preterm labour in mice. To prevent this, progesterone, which promotes the NOS expression and the corresponding NO synthesis accompanied by a decrease in the contractile activity of the uterus, was used [94].

The maternal and fetal circulatory systems are adapted during pregnancy. The state of uteroplacental circulation directly depends on the NO. Decreased NO levels in the blood of pregnant women can lead to an imbalance in the fetoplacental circulation, accompanied by the development of placental insufficiency. It causes chronic oxygen starvation and hypoxia of the fetus, resulting in neonatal disorders [95]. Administration of L-arginine leads to positive changes in the fetoplacental circulation in patients with preterm labour [95].

A fairly common cause of abortion is an antiphospholipid syndrome - an autoimmune disease of various etiologies, which is accompanied by the production of antibodies against phospholipids and associated proteins. Phospholipid syndrome occurs against the background of hyperproduction of proinflammatory cytokines. The elevated levels of proinflammatory cytokine TNF- $\alpha$ were observed in the serum of women suffering from miscarriages [96]. Serum levels of the anti-inflammatory cytokine IL-6 were high, while proinflammatory INF- $\gamma$ and TNF- $\alpha$ 
were low in pregnant women with a normal pregnancy. This effect of proinflammatory cytokines may be due to excessive expression of iNOS and hyperproduction of reactive nitrogen and oxygen species in uterine tissues. The ambiguous effect of NO on the contractile function of the myometrium during pregnancy has been demonstrated in a model of antiphospholipid syndrome. NO causes relaxation at moderate concentrations, but a significant reduction in its formation leads to spontaneous abortion and preterm labour. Hyperproduction of reactive nitrogen and oxygen species mediated by the activity of iNOS increases the contractile activity of the myometrium, resulting in an increased risk of miscarriage [97].

The use of NO donor, S-nitroso-N-acetyl-dlpenicillamine (SNAP), prevents the inhibitory effect of antiphospholipid antibodies on eNOS [98]. eNOS activator hydroxychloroquine [99] reduces the procoagulant state and improves vascular function in antiphospholipid syndrome. The decrease in the incidence of preterm labour at this pathology occurs under the influence of morphine, which is attributed to its ability to stimulate the release of NO [97]. The use of L-NAME removes this effect, which confirms the role of the NO system in the development of antiphospholipid syndrome.

The source of NO can be the placenta. iNOS and eNOS were identified in the vascular endothelium and syncytiotrophoblasts of the placenta. It is suggested that placental NO may act as a paracrine regulator of myometrial contraction [100]. Nerve endings containing nNOS and providing uterus nitrergic innervation were identified [17, 18, 21, 87].

Thus, the formation of nitric oxide in the tissues of the uterus, vessels, nerve endings and placenta has been ascertained. NO is synthesized primarily by iNOS and eNOS and significantly depends on the type of tissue and the functional state of the organ, which indicates its physiological significance.

\section{Biochemical mechanisms of involvement of nitric oxide in the regulation of $\mathrm{Ca}^{2+}$-dependent contractile activity of the myometrium}

The published data allow making assumptions about the role of nitric oxide in the processes that inhibit the contractile response of the uterus during pregnancy upon elevated progesterone levels [6-8, 75]. Since the 1990s, experimental data on the enhancement of NO production in uterine tissues, geni- tal tract, placenta (decidual membrane) during pregnancy have been reported. It has been suggested that NO performs a tocolytic function. The amount of NO and the tissue sensitivity to NO decrease before labor [6-10, 101]. Nitric oxide is thought to provide relative non-excitability of the myometrium during pregnancy and control the initiation of contractile activity of the myometrium during labor. Nitric oxide donors cause relaxation of women and animal myometrium in a state of functional rest and during pregnancy [11, 13, 102-107]. Therefore, the administration of the nitric oxide donors has been suggested to be effective in inhibiting myometrial contraction to prevent preterm labour [62, 88, 108].

In our studies, the treatment of uterine myocytes with nitrocompounds, namely NO donor (sodium nitroprusside (SNP)) and NO precursor (sodium nitrite (SN)), was shown to prevent an increase in the $\mathrm{Ca}^{2+}$ concentration in the myoplasm caused by the oxytocin or carbachol (acetylcholine receptor agonist) action (Fig. 3).

In cells of different types of smooth muscle, the relaxing effect of NO is associated with an increase in cGMP content in the myoplasm [3]. The L-arginine/NO/cGMP regulatory mechanism has been identified in the myometrium of humans, rats, guinea pig and rabbits. In all these species, this mechanism is activated during pregnancy [102, 104107]. Plasma and urine levels of cGMP, nitrates and nitrites increased during pregnancy in rats and sheep [109, 110].

In isolated myometrial strips of pregnant rats, gaseous NO, SNP, 8-bromo-cGMP (membranepermeable analogue of cGMP) and L-arginine were shown to inhibit both spontaneous myometrial contraction and carbachol-stimulated, but not for highpotassium depolarization of the plasma membrane [109-112]. There is evidence that the NO effects associated with sGC activation and cGMP formation are controlled by progesterone, particularly in pregnant rats $[76,113]$.

The level of cGMP in the myocytes of nonpregnant women, rats and guinea pigs increased in vitro in response to SNP treatment. Another NO donor, nitroglycerin, decreased the rate of contractions of myometrial strips in non-pregnant and pregnant women along with increased intracellular cGMP [76, 105, 112].

According to the results of some research groups, the increase in the content of cGMP in the myoplasm under the $\mathrm{NO}$ action is not a necessary 


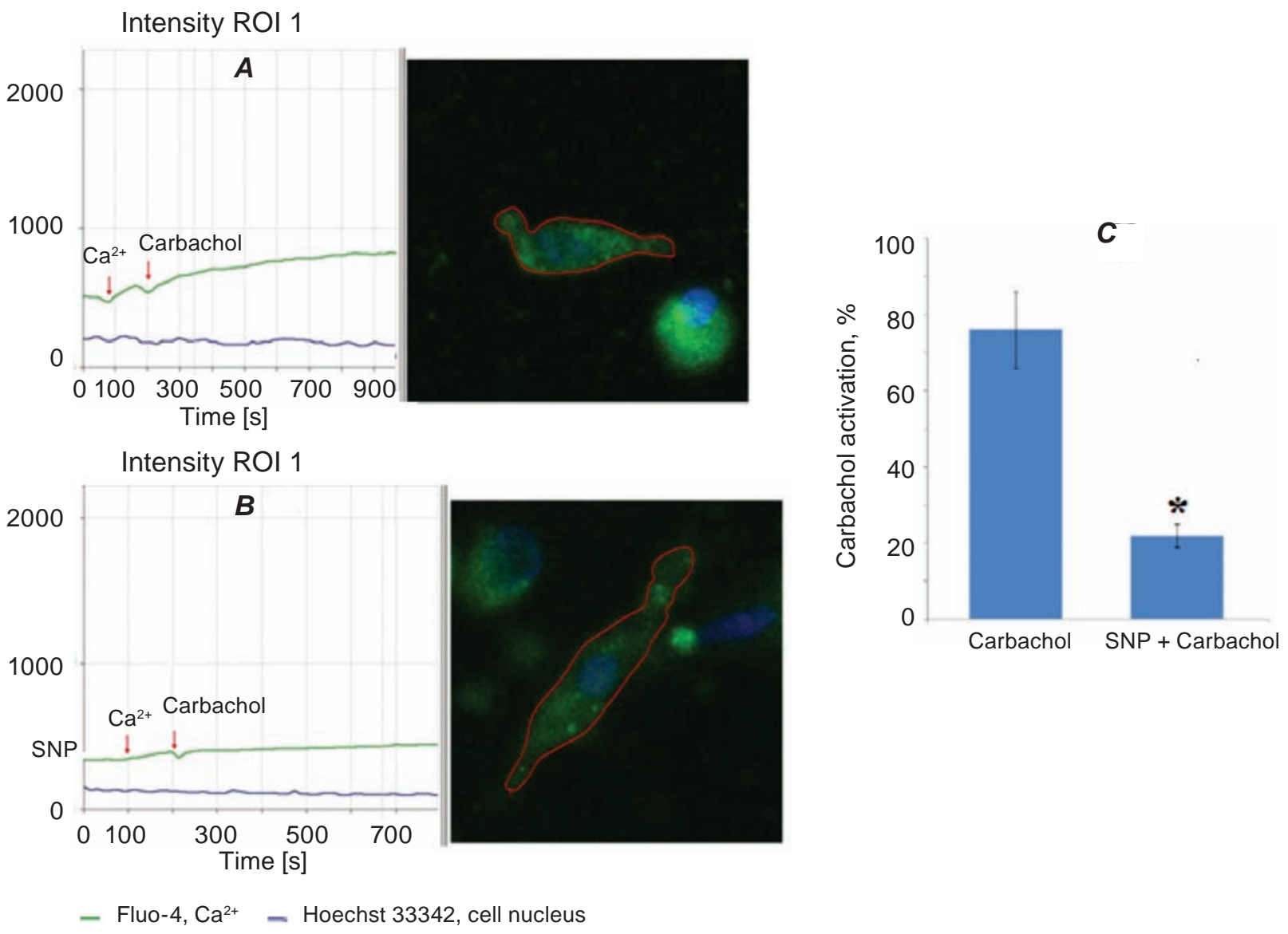

Fig. 3. Carbachol-activated increase in myoplasm $\mathrm{Ca}^{2+}$ : in control (A) and in pre-treated (for 5 min) cells by NO donor - $0.1 \mathrm{mM}$ SNP (B). For quantitative analysis, 6-7 myocytes from different experiments were used (C); (unstimulated cells is $0 \%$ ), $* P<0.01$

and sufficient condition for the physiological response [103]. The significance of the mechanisms of cGMP-dependent relaxation of the myometrium has been questioned in the studies on smooth muscle cells of non-pregnant and pregnant women, primates, rats and guinea pigs uterus [11, 13, 102-104, 114]. It has been demonstrated that NO donors cause relaxation of mechanical tension regardless of the presence of sGC inhibitors [108-114]. Suppression of spontaneous contractions of non-pregnant women in the presence of L-arginine and SNP through cGMPindependent pathway has been shown [115].

The cGMP-independent mechanism of NO action in smooth muscle, in particular in the myometrium, can be a direct chemical modification (S-nitrosylation) of ion channels and pumps, which leads to a change in their activity and can be carried out by highly reactive nitrosylating nitric oxide derivatives, such as nitrosonium cation $\left(\mathrm{NO}^{+}\right)$, nitric dioxide $\left(\mathrm{NO}_{2}\right)$, nitroxyl-anion (NO-) etc. [1, 7, 82, 116]. These NO redox forms are generated in solutions with the widely used nitrocompounds SNP and SN [116]. The regulatory effect of NO via S-nitrosylation of proteins that support pregnancy in the human myometrium was proved [62, 74, 117]. It was shown that in preterm labour, there is an increase in S-nitrosylation of several key regulatory proteins: calponin-1, profilin-1, regulatory light polypeptide myosin 9 and light polypeptide myosin 6 , thioredoxin and transgelin. Along with this, there is a decrease in the level of S-nitrosylation of serum albumin, hemoglobin subunits, glutathione-S-transferase $\mathrm{P}$, which are involved in the storage and transport of NO into the cell [74]. There is an increase in the expression of S-nitrosoglutathione reductase and, accordingly, a decrease in the content of S-nitrosoglutathione (the main NO-transporting and depositing molecule involved in transnitrosylation) in the myometrium of women in case of preterm labour. The efficiency of NO-dependent relaxation of the myometrium decreases under these conditions. The activity of sGC was not directly related to these processes [117]. 
Clinical studies have revealed that the NO donor nitroglycerin reduces the risk of preterm labour $[114,118]$. Nitroglycerin causes hyperpolarization of the myocyte membrane in pregnant rats, possibly by cGMP-dependent activation of plasmalemma $\mathrm{K}^{+}$-permeability. However, the relaxation of the myometrium of non-pregnant rats without increasing the level of cGMP is also observed. Relaxation of monkey myometrium induced by S-nitro-L-cysteine was inhibited by $\mathrm{K}^{+}$-channel inhibitor tetraethylammonium. NO donors and L-arginine have been shown to promote the opening of large-conductance $\mathrm{Ca}^{2+}$ activated $\mathrm{K}^{+}$-channels $\left(\mathrm{BK}_{\mathrm{Ca}}\right)$ in myometrial cells in pregnant women, and NOS/PKG inhibitors block the conduction of these channels. It has been suggested that NO (or its donors) can relax the myometrium by directly activating sGC and/or $\mathrm{K}_{\mathrm{Ca}}$ channels [6, 119, 120]. It has been shown in human myometrium that during pregnancy, there is a shift in the resting plasmalemma potential towards more negative values, but this effect is not associated with increased expression of $\mathrm{BK}_{\mathrm{Ca}}$ [119].

A certain species-specificity of uterine sensitivity to nitric oxide has been observed. There is also a dependence of the physiological response on the chemical nature of the NO donors. It was demonstrated on human and rat uterine strips that nitric oxide as well as substrate and donors of NO inhibit spontaneous contractions, while the NOS inhibitor L-NAME stimulates. At the same time, in vivo, L-NAME did not cause myometrium contraction in rats but caused in guinea pigs [113]. The study of the NO effect on the parameters of spontaneous myometrium contractions in rats revealed that in the presence of sodium nitroprusside, there was a significant decrease in the amplitude and frequency of spontaneous contractions, and an increase in the normalized maximum rate of the relaxation phase [121]. The myometrium of rats is insensitive to nitroglycerin [122]. The human myometrium is insensitive to L-arginine, but has a much higher and pregnancy stage-dependent sensitivity to NO donors compared to other mammals studied. It was suggested [93] that the human myometrium may be a target of NO synthesized outside this tissue, while the rat myometrium is both a source and a target of NO. Inhibition of NOS activity by L-NAME or aminoguanidine and administration of NO donor nitroglycerin in vivo did not change the contractile activity of the myometrium in non-pregnant and pregnant sheep [111]. The different sensitivity of the myometrium to various compounds that alter the metabolism and concentration of nitric oxide may depend on their chemical nature and molecular mechanism of the actions. At the same time, the differences in the effect of these compounds on the myometrium of different animal species indicate certain differences in the mechanisms of regulation of uterine contractile function.

Thus, the analysis of experimental data outlines the following NO activities during pregnancy: restriction of platelet aggregation in the placental barrier, regulation of placental blood flow, inhibition of myometrial contraction [6, 22, 88]. At the same time, the biochemical mechanisms by which nitric oxide controls the contractile function of the myometrium are not yet fully understood. An increase in the $\mathrm{Ca}^{2+}$ concentration in the myoplasm is the first and main condition for the development of contraction. The second condition is the formation of a $\mathrm{Ca}^{2+}-$ calmodulin complex with subsequent activation of the contractile apparatus [14, 78]. Accordingly, $\mathrm{Ca}^{2+}$ homeostasis maintenance systems may be the main targets of NO action as a muscle relaxant [89, 123]. The authors of the presented review carried out a series of studies in this direction.

In particular, we studied the effect of NO on $\mathrm{Ca}^{2+}$ transport in the plasma membrane of uterine myocytes. An increase in the plasmalemma $\mathrm{Ca}^{2+}$ permeability and a decrease in the activity of $\mathrm{Ca}^{2+}, \mathrm{Mg}^{2+}$-ATPase under the action of nitric oxide depending on the time and concentration of nitrocompounds were demonstrated [124]. These membrane and ionic effects are able to provide a local increase in the $\mathrm{Ca}^{2+}$ concentration in the subplasmallemal region and stimulate $\mathrm{Ca}^{2+}$-dependent processes in the membrane, in particular, enhanced NO synthesis and activation of $\mathrm{Ca}^{2+}$-dependent $\mathrm{K}^{+}$-channels. It was proved that $\mathrm{NO}$ causes a pronounced polarization of the plasma membrane of myometrial cells only at physiological concentrations of extracellular $\mathrm{Ca}^{2+}$. The growth of transmembrane potential is not observed in the conditions of application of plasmalemma $\mathrm{K}^{+}$-channels blockers [125]. Thus, nitric oxide causes $\mathrm{Ca}^{2+}$-dependent polarization of the plasma membrane of myometrial cells due to the activation of membrane $\mathrm{K}^{+}$-permeability. An additional factor contributing to the plasma membrane hyperpolarization may be cGMP-dependent stimulation of $\mathrm{Na}^{+}, \mathrm{K}^{+}$ATPase [124].

The above effects may cause effective inhibition by nitrocompounds of the high-potassium depolarization of uterine myocytes over time (Fig. 4). 


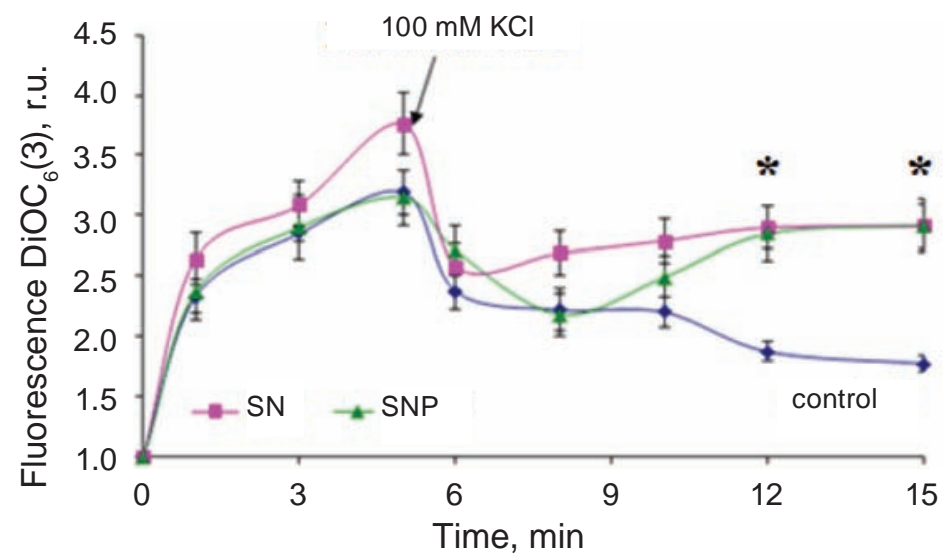

Fig. 4. Influence of $0.1 \mathrm{mM} S \mathrm{SN}$ and SN on the development of high-potassium depolarization over time under conditions of uterine myocyte preincubation with nitrocompounds for $15 \mathrm{~min}, M \pm m, n=5$. To exclude the effect of mitochondria, cells were preincubated with $5 \mathrm{mM}$ sodium azide for $5 \mathrm{~min}, n=5$

The cell autofluorescence [125] was taken as "1" with changes.

Under the influence of NO, the energydependent accumulation of $\mathrm{Ca}^{2+}$ in the sarco(endo) plasmic reticulum and mitochondria increases and its passive release from the sarco(endo)plasmic reticulum decreases. This can compensate for NOinduced $\mathrm{Ca}^{2+}$ uptake into myocytes and inhibit $\mathrm{Ca}^{2+}$-induced $\mathrm{Ca}^{2+}$ release $[124,126]$. Nitric oxide inhibits the store-operated entry of $\mathrm{Ca}^{2+}$ into myocytes, which correlates with increased reticulum $\mathrm{Ca}^{2+}$ load under the action of the studied nitrocompounds. It is known that store-operated $\mathrm{Ca}^{2+}$ transport is an important component of activation of $\mathrm{Ca}^{2+}$-dependent contractile activity of the myometrium by oxytocin [14]. We have demonstrated inhibition of the formation of the $\mathrm{Ca}^{2+}$-calmodulin complex under the action of nitrocompounds, which is the main link in triggering contractions in smooth muscle [124]. Therefore, these results suggest that nitric oxide may inhibit the electro(pharmaco)mechanical coupling in the myometrium at key stages.

The ability of nitric oxide to relax the myometrium determines the interest in the use of NO donors and precursors in obstetrics and gynecology [88]. But insufficient information about $\mathrm{Ca}^{2+}$ dependent subcellular mechanisms of its action hinders the development and use of effective pharmaceuticals. Thus, it is important to conduct systematic investigations aimed at studying the peculirities of NO formation in individual myocyte compartments involved in maintaining $\mathrm{Ca}^{2+}$-homeostasis and are the target for $\mathrm{NO}$ action. Mitochondria are an essential coordinating center of the cell, which pro- vides coupled processes of bioenergy, metabolism and $\mathrm{Ca}^{2+}$ signaling. In normoxia, mitochondria can oxidize the guanidine group of L-arginine to form nitric oxide, which is an important regulator of the functional activity of the mitochondria themselves.

\section{Mitochondria as a source and target for nitric oxide in the myometrium}

In some tissues, mitochondria are considered an important source of nitric oxide [23-28]. There is a lack of information in the available scientific literature on the NO formation, catalytic and kinetic properties of the NO-synthase system of smooth muscle mitochondria, in particular myometrial cells.

It was shown the existence of mitochondrial NOS (mtNOS) in rat intact succinate-energized liver mitochondria [127]. This enzyme generated NO and L-citrulline in the presence of L-arginine and was $\mathrm{Ca}^{2+}$-dependent and constitutively active. mtNOS function was associated with the inner mitochondrial membrane, depended on the intensity of mitochondrial respiration, and was controlled by membrane potential; L-arginine analogs inhibited the enzyme [127]. NO synthesis in mitochondria was also detected in digitonin-permeabilized ventricular myocytes [128].

Detailed analysis of the amino acid composition of mtNOS revealed that its structure corresponds to the primary sequence of nNOS [129]. Mitochondrial NO synthase is assumed to be a splice variant of fulllength $\mathrm{nNOS} \alpha$, that differ from already identified, with a molecular weight of $144 \mathrm{kDa}$. Immunocolocalization of mtNOS with mitochondrial markers (succinate dehydrogenase, cytochrome c-oxidase) 
gives further proof of its localization in the inner mitochondrial membrane [24, 26, 27, 44].

mtNOS activity is maximal at the optimal functioning of the electron transport chain, in particular, complex I, which is thought to be a source of electrons for the functioning of the enzyme as the blocking complex I inhibits the activity of mtNOS [32, 130-131]. NO synthesis increases exponentially with the electric potential of the inner membrane, and the dependence of NO production on intramitochondrial $\mathrm{pH}$ (in the range of 5.5-8.5) is bell-shaped with a maximum at $\mathrm{pH} 7.4[26,28,132]$.

Thus, the results of some studies indicate that the nitric oxide synthesis by mitochondria significantly depends on their energy level, the electric potential and the intensity of exogenous $\mathrm{Ca}^{2+}$ influx into the matrix. Experimental data indicate that mtNOS is constantly expressed in mitochondria, is a membrane-bound enzyme, and resembles constitutive NOS in its properties, namely the neuronal isoform. Currently, mitochondrial localization of NOS is reliably shown in some organs and tissues of mammals (liver, thymus, kidneys, brain, cardiomyocytes, diaphragm) [128, 129, 133-136].

We demonstrated for the first time the formation of NO in the mitochondria of myometrium using laser confocal microscopy and colocalization analysis of specific fluorescent dyes [137]. Subsequently, a study of the biochemical properties of nitric oxide synthesis in mitochondria of uterine smooth muscle was performed. In particular, the conditions for determining NO-synthase activity in isolated mitochondria of rat myometrium using a DAF-FM fluorescent probe and flow cytometry were established. Optimal NO-synthase activity requires the presence of $\mathrm{Ca}^{2+}$, NADPH and L-arginine in the incubation medium (Fig. 5, A) [131]. The key kinetic parameters of this enzymatic reaction were calculated: the value of the Michaelis constant for L-arginine was found to be $28.9 \pm 9.1 \mu \mathrm{M}$, and the activation constant for $\mathrm{Ca}^{2+}$ was $44.4 \pm 14.5 \mu \mathrm{M}$, which have physiological significance [131]. It was proved that the biosynthesis of nitric oxide by mitochondria significantly depends on the level of their energization. In the absence of exogenously added respiratory substrates, isolated mitochondria synthesized NO with little efficiency (Fig. 5, B). The addition of pyruvate and succinate to the incubation medium stimulated their oxidation and the functioning of the electron transport chain, energized mitochondria and enhanced the nitric oxide synthesis. A similar effect on NO-synthase activity had a known inhibitor of $\mathrm{H}^{+}-$ channel $\mathrm{H}^{+}$-ATPase ( $\mathrm{F}_{\mathrm{o}}$ complex) oligomycin (Fig. 5, $B$ ). The addition of ADP (inorganic phosphate and $\mathrm{Mg}^{2+}$ are in the incubation medium) to the energized mitochondria provided conditions for the synthesis of ATP and weakened NO-synthase activity (Fig. 5, $B$ ). Blocking the electron transport chain complex I by rotenone or the complex III by antimycin A resulted in a significant decrease in NO biosynthesis by energized mitochondria [131]. A similar effect was caused by the introduction into the incubation medium of the protonophore carbonyl cyanide 3-chlorophenylhydrazone (CСCP), which quickly dissipates the electrochemical proton gradient on the inner mitochondrial membrane [131]. Inhibitors of the constitutive isoforms of $\mathrm{NO}$ synthase $\mathrm{N}^{\mathrm{G}}$-nitroL-arginine (Fig. 5, C) and 2-aminopyridine [138] at concentrations of $25 \mu \mathrm{M}$ and $100 \mu \mathrm{M}$, respectively, inhibited by almost $50 \%$ the production of NO by mitochondria. Inhibition of mtNOS was exerted by ruthenium red, the blocker of $\mathrm{Ca}^{2+}$ transport in the inner mitochondrial membrane (Fig. 5, D), as well as by trifluoperazine and calmidazolium (calmodulin antagonists) [138].

Among the wide range of mitochondria functions such as bioenergetics, regulation of the metabolic processes, the source of reactive oxygen species, apoptosis that determine the key role of these organelles for normal cell life, their importance in the maintenance of intracellular $\mathrm{Ca}^{2+}$ homeostasis is the crucial one. Mitochondria have been shown to be high-capacity $\mathrm{Ca}^{2+}$ stores. These organelles terminate the $\mathrm{Ca}^{2+}$ signal, maintain a low physiologically significant concentration of this cation in the cytosol, and thus protect cells from $\mathrm{Ca}^{2+}$ overload [81, 86, 139, 140]. Disorder of $\mathrm{Ca}^{2+}$-transport system localized in mitochondrial membranes may underlie the disturbance of $\mathrm{Ca}^{2+}$-homeostasis and the resulting cell pathology. These processes are essential for the work of muscle tissue because its main function, contractile activity, is a $\mathrm{Ca}^{2+}$-dependent process. The biological activity of mitochondria is also largely $\mathrm{Ca}^{2+}$ dependent. The increase in the concentration of $\mathrm{Ca}^{2+}$ in the matrix activates the enzymes of the citric cycle and the synthesis of ATP [141, 142], while the overload of the organelle with the cation induces cell death [143]. Mitochondria play an important role in $\mathrm{Ca}^{2+}$ signaling and $\mathrm{Ca}^{2+}$-dependent contraction of the smooth muscles [144, 145].

We confirmed the significance of the electrochemical proton gradient on the inner mitochondrial membrane in maintaining the optimal concentration 

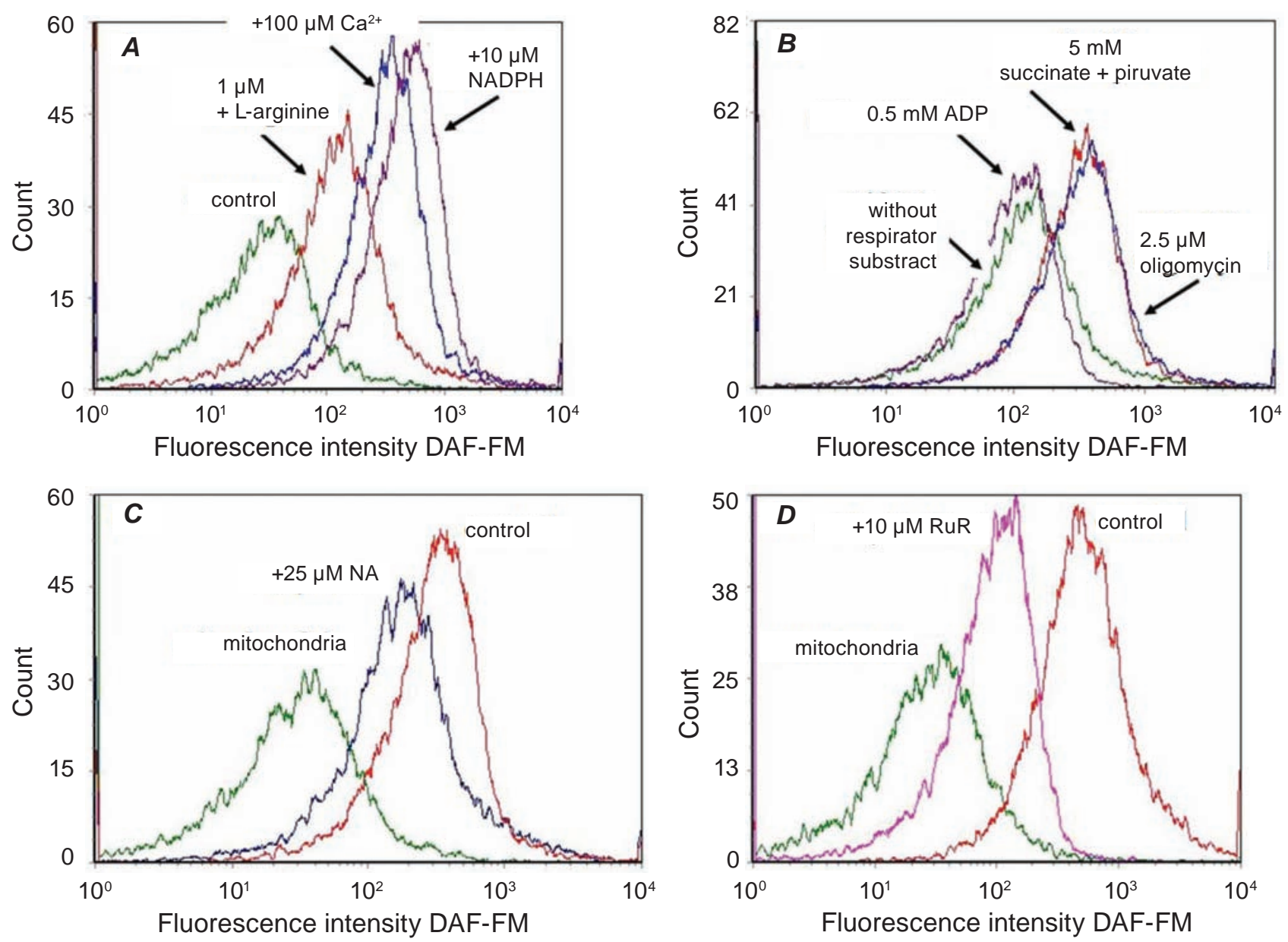

Fig. 5. Dependence of NO synthesis in mitochondria on the presence of substrate and cofactors in the incubation medium (A), respiratory substrates and electron transport chain modifiers (B), as well as in the presence of $N^{G}$-nitro-L-arginine (NA) (C) and ruthenium red (RuR) (D). Shifts of DAF-FM fluorescence intensity peaks were registered with the use of the flow cytometry in different incubation media

of $\mathrm{Ca}^{2+}$ in the myoplasm using laser confocal microscopy and $\mathrm{Ca}^{2+}$-sensitive fluorescent probe Fluo-4 AM (Fig. 6).

This proves the essential role of these subcellular structures in ensuring $\mathrm{Ca}^{2+}$ homeostasis in uterine smooth muscle cells. Dissipation of the hydrogen ion gradient by protonophore CCCP results in a sharp increase in the $\mathrm{Ca}^{2+}$ concentration in the cytosol (Fig. 6) [145] due to the suppression of the functioning of the $\mathrm{Ca}^{2+}$-uniporter.

Disbalance of the coordinated functioning of $\mathrm{Ca}^{2+}$-transport systems localized in the mitochondrial inner membrane can lead to the phenomenon of $\mathrm{Ca}^{2+}$-overload matrix, hyperpolarization, disruption of $\mathrm{Ca}^{2+}$-dependent metabolism of reactive nitrogen/ oxygen species and their hyperproduction. The nitrosative/oxidative stress caused by these processes, under the poor functioning protective systems, re- sults in mitochondrial dysfunction. Mitochondrial dysfunction is manifested in the disruption of the electron transport chain, irreversible depolarization of the inner membrane, loss of osmotic balance between the mitochondrial matrix and myoplasm, etc. [24, 32, 42, 56, 146, 147]. These phenomena accompany contractile dysfunction of smooth muscle in pathological conditions of various genesis. Disorders of smooth muscle contractile activity, some authors classify as "mitochondrial diseases" [26, 32, 56, 70, 85, 148-150]. Excess NO production on the background of increased $\mathrm{O}_{2}^{-}{ }^{-}$formation in mitochondria is accompanied by the generation of significant amounts of peroxynitrite, which can cause apoptosis. The reaction of $\mathrm{NO}$ with $\mathrm{O}_{2}{ }^{-}$is considered an important factor in reducing the bioavailability and physiological activity of nitric oxide in mitochondria $[31,56,58]$. 


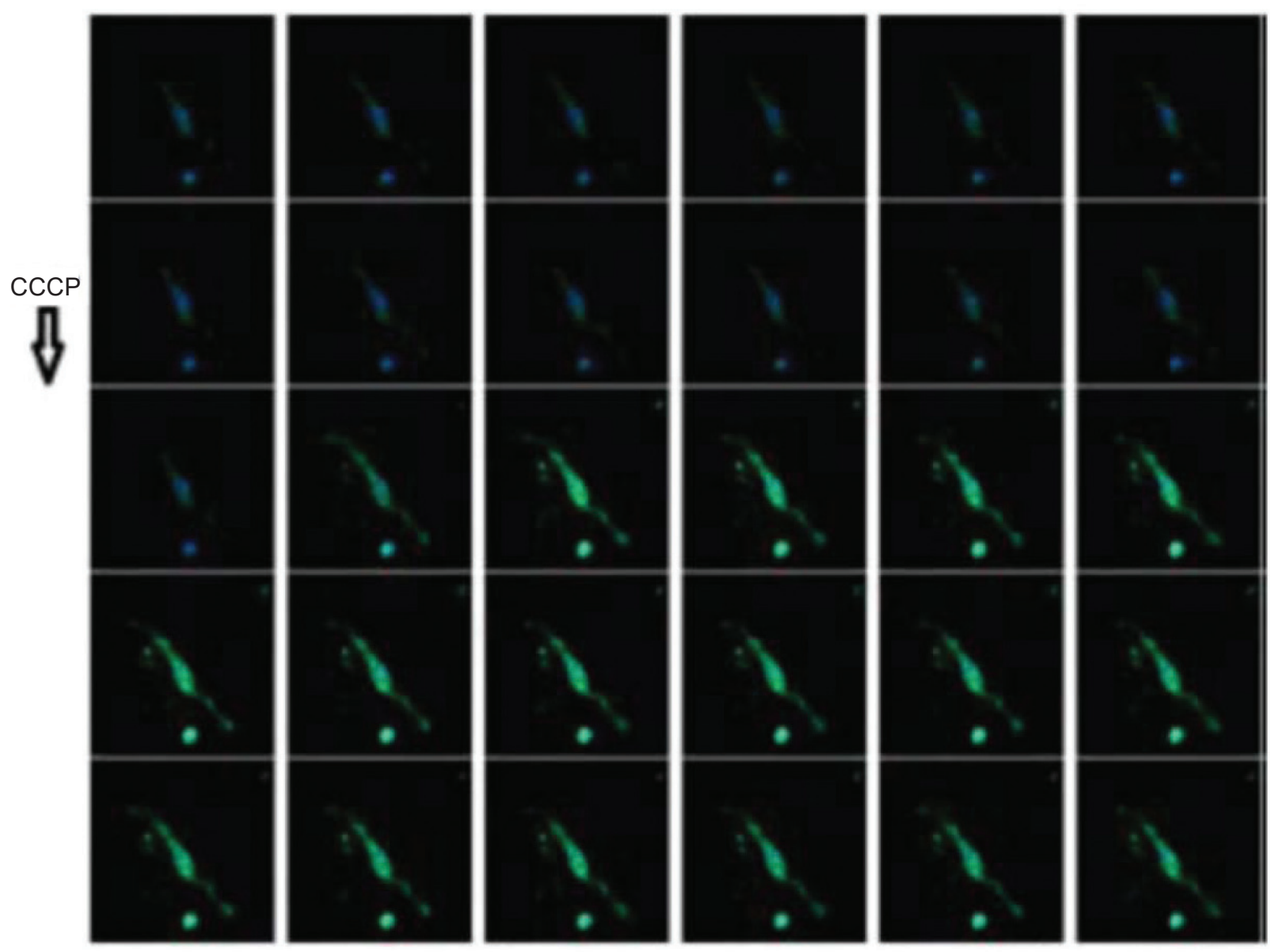

Intensity ROI 1
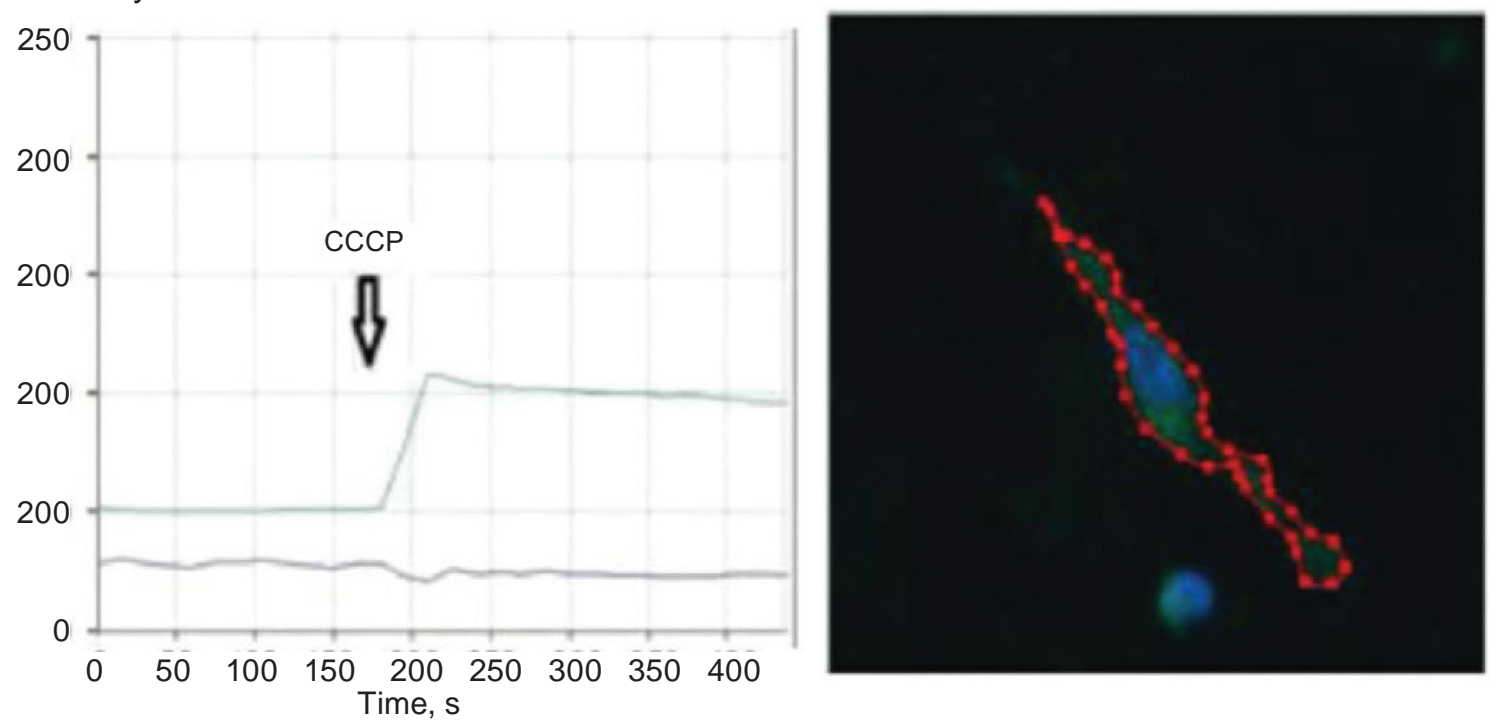

Fig. 6. Visualization of the process of increasing the $\mathrm{Ca}^{2+}$ concentration in the myoplasm under the action of $10 \mu M$ protonophore CCCP using Fluo-4 AM (top panel) and numerical interpretation of this process, ROI function (bottom panel). Laser confocal microscopy data [145] 
Over the last twenty years, NO has been found to regulate energy, metabolic and transport processes in mitochondria. The mitochondrial inner membrane, like matrix enzymes, is an effective target for nitrocompounds due to the high content of thiol residues, iron-sulfur centers, heme groups, and the presence of superoxide anion. Nitric oxide at physiological nanomolar concentrations is able to inhibit reversibly the activity of cytochrome c-oxidase resulting in a decrease in the intensity of functioning of the electron transport chain, oxidative phosphorylation and oxygen consumption by mitochondria. These effects are considered to be regulatory ones. Nitric oxide or its derivatives also interact and inhibit the functioning of the I and III complexes of the respiratory chain [26, 32, 149, 151]. A number of researchers consider nitric oxide at physiological concentrations as a protective molecule that can defend organelles from dysfunction caused by hyperpolarization of the inner membrane, excessive production of reactive oxygen species and oxidative stress [32, 44, 65, 149, 152, 153]. NO is thought to be an important part in maintaining the optimal concentration of $\mathrm{Ca}$ ions in both the myoplasm and mitochondrial matrix, and this has been confirmed in recent studies [25, 32, 141, 142, 147, 153]. The NO/ cGMP-dependent decrease in the electric potential on the inner mitochondrial membrane that affects the intensity of electrophoretic uptake of $\mathrm{Ca}^{2+}$ has been demonstrated [32]. Nitric oxide regulates the activity of $\mathrm{Ca}^{2+}$-dependent NADH-dehydrogenases and Krebs cycle enzymes by modulating $\mathrm{Ca}^{2+}$ homeostasis in mitochondria [141, 142].

There is compelling evidence for the existence of at least two $\mathrm{Ca}^{2+}$ transport systems located in the inner membrane in the myometrial mitochondria: $\mathrm{Ca}^{2+}$-uniporter - electrophoretic low-affinity and high-capacity system of energy-dependent $\mathrm{Ca}^{2+}$ accumulation, and $\mathrm{H}^{+}-\mathrm{Ca}^{2+}$-exchanger [154-157]. The first is of particular importance for the reticular-mitochondrial $\mathrm{Ca}^{2+}$-functional unit, ensuring the accumulation of cation in local high $\mathrm{Ca}^{2+}$ concentration near the sarco(endo)plasmic reticulum. The structural basis of the $\mathrm{H}^{+}$- $\mathrm{Ca}^{2+}$-exchanger in mammals was identified to be LETM protein [158]. This reverse transporter is more affinity for $\mathrm{Ca}^{2+}$ and able to provide both $\mathrm{Ca}^{2+}$ release and $\mathrm{Ca}^{2+}$ accumulation depending on the current $\mathrm{Ca}^{2+}$ and $\mathrm{H}^{+}$concentrations. It was found that the $\mathrm{Ca}^{2+}$ release from the myometrial mitochondria is carried out by $\mathrm{H}^{+}-\mathrm{Ca}^{2+}$-exchanger with stoichiometry $1 \mathrm{Ca}^{2+}: 1 \mathrm{H}^{+}$, which is activated at physiological $\mathrm{pH}$ values, inhibited by monoclonal anti-LETM1 antibodies and regulated by calmodulin [157].

Ruthenium red-sensitive $\mathrm{Ca}^{2+}$ accumulation by energized mitochondria is stimulated by nitric oxide

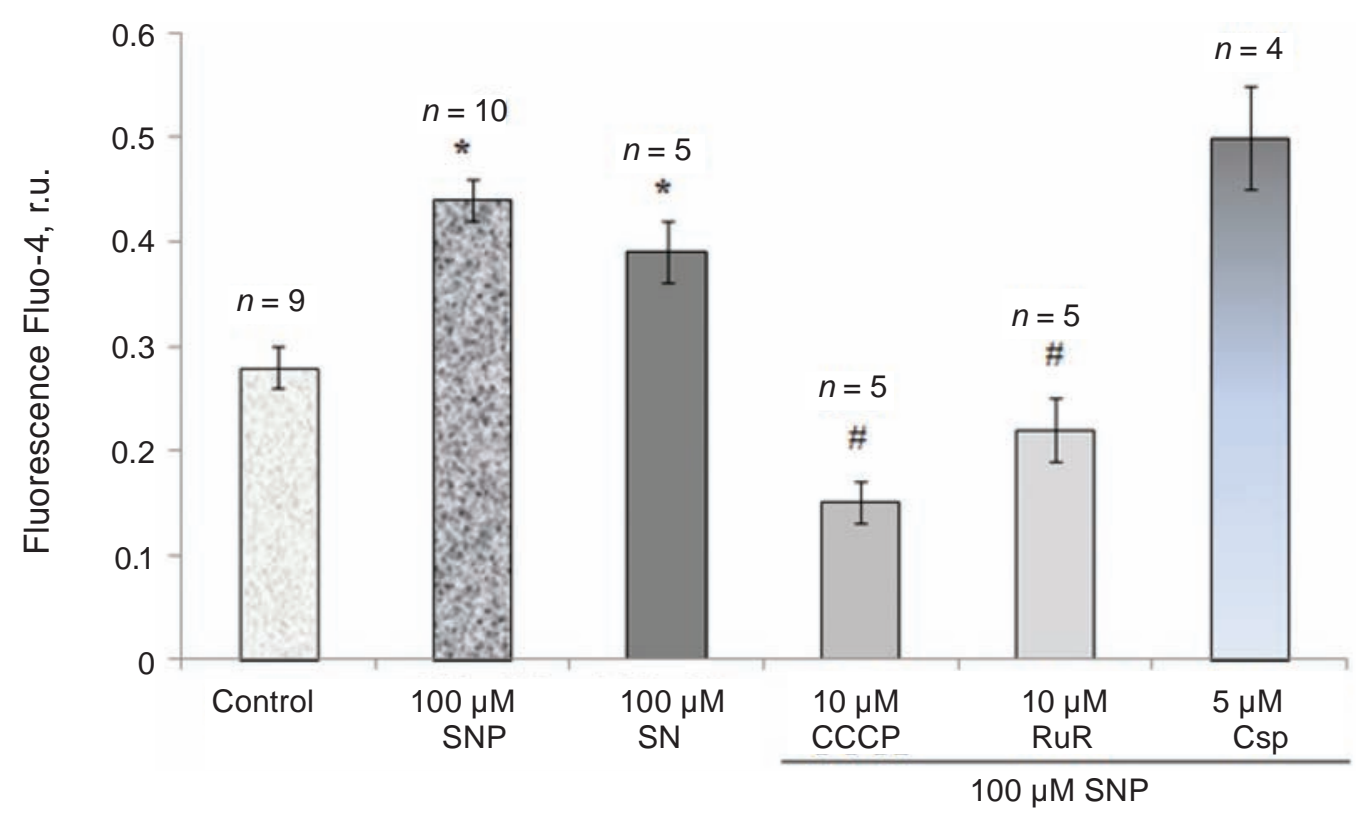

Fig. 7. The effect of nitrocompounds on the energy-dependent $\mathrm{Ca}^{2+}$ accumulation in mitochondria in the presence of modifiers of transmembrane cation metabolism. The data are presented as mean $\pm S E M,{ }^{*}$ changes are significant with respect to control, $P \leq 0.05$, "with respect to the action of $100 \mu M S N P, P \leq 0.05$ 
(Fig. 7) [156]. This effect is mediated by activation of the $\mathrm{Ca}^{2+}$-uniporter, as it is inhibited by the ruthenium red and protonophore CCCP, which disrupt the driving force for the energy-dependent $\mathrm{Ca}^{2+}$ accumulation. At the same time, it does not depend on the functioning of the permeability transition pore due to insensitivity to cyclosporine A. The stimulating effect of NO on energy-dependent $\mathrm{Ca}^{2+}$ accumulation may be important for a rapid decrease in cation plasma concentrations following $\mathrm{Ca}^{2+}$ transient.

However, $\mathrm{H}^{+}-\mathrm{Ca}^{2+}$-exchanger is completely resistant to nitric oxide. Negative results were observed both in the presence of nitrocompounds (Fig. 8, A) and under stimulation of endogenous production of nitric oxide by mitochondria (Fig. 8, $B$ ).

The absence of the NO effect on the $\mathrm{H}^{+}-\mathrm{Ca}^{2+}-$ exchanger allows the $\Delta \mathrm{pH}$-dependent $\mathrm{Ca}^{2+}$ release from the mitochondrial matrix and its subsequent accumulation by the sarco(endo)plasmic reticulum. Nitric oxide has been shown to stimulate the energy-dependent $\mathrm{Ca}^{2+}$ influx into the reticulum [126]. Thus, under increased NO concentration in the myometrium, there is a possibility of normal mitochondrial-reticulum compartment functioning (of note, the affinity of SERCA for $\mathrm{Ca}^{2+}$ is higher than that of mitochondrial uniporter [154]) and subsequent $\mathrm{Ca}^{2+}$ release from the cell due to the interaction of transport systems of the peripheral reticulum and plasma membrane. Thus, we can assume the existance of membrane mechanisms that protect mitochondria from dangerous $\mathrm{Ca}^{2+}$ overload.
NO has been shown to have a protective effect on mitochondria due to a moderate decrease (about $17 \%)$ in the electric potential on their inner membrane [159]. One of the possible causes for this is the slowdown of the electron transport chain. In particular, we observed inhibition of $\mathrm{FADH}_{2}$ oxidation to fluorescent FAD in isolated mitochondria (Fig. 9) [160].

This effect occurred with the use of nitrocompounds (Fig. 9, $A$ ) or with endogenous stimulation of NO synthesis by mitochondria (Fig. 9, $B$ ) and can be attributed to inhibition of the respiratory chain complex II. A moderate decrease in mitochondria electric potential can be considered as a factor of protection against $\mathrm{Ca}^{2+}$ overload and hyperproduction of reactive oxygen species. In addition, nitric oxide effectively prevented the high-calcium swelling associated with disruption of $\mathrm{K}^{+}$transport in the inner membrane and the opening of the permeability transition pore [161].

The results presented in this section support the view that mitochondria are an essential source of NO in uterine myocytes. Nitric oxide regulates specifically $\mathrm{Ca}^{2+}$ transport in the inner mitochondrial membrane, inhibits $\mathrm{FADH}_{2}$ oxidation in the electron transport chain, moderately reduces the electric potential and prevents mitochondrial swelling. Together, these data suggest that NO acts in the myometrial mitochondria as a regulator of $\mathrm{Ca}^{2+}$ homeostasis, bioenergetic processes and protector. However, we still lack information about the rela-
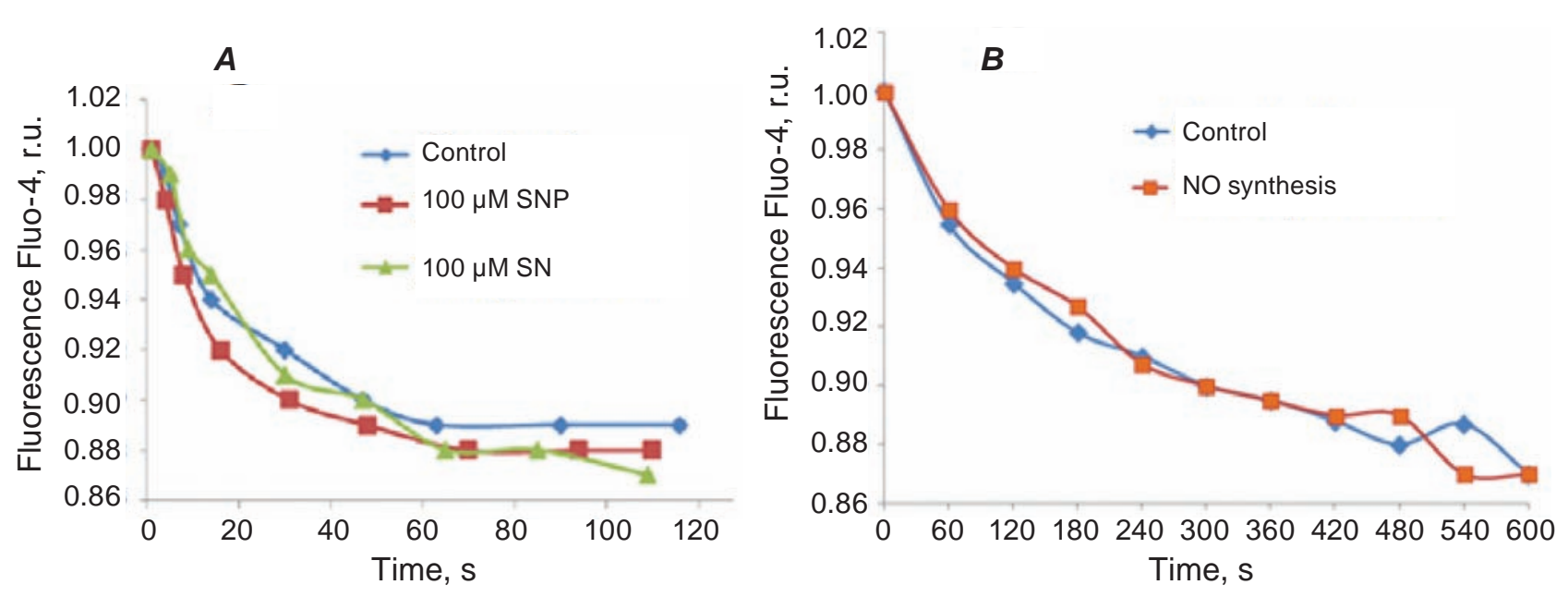

Fig. 8. Nitrocompounds (A) and activation of NO synthesis (in the presence of $50 \mu M$ L-arginine, $10 \mu M$ $\mathrm{NADPH}$ and $\left.\mathrm{BH}_{4}\right)(\mathbf{B})$ does not affect $\triangle p H$-induced $\mathrm{Ca}^{2+}$ transport from mitochondria. These data represent typical experiments. Standard incubation medium ( $p H$ 6.5) 

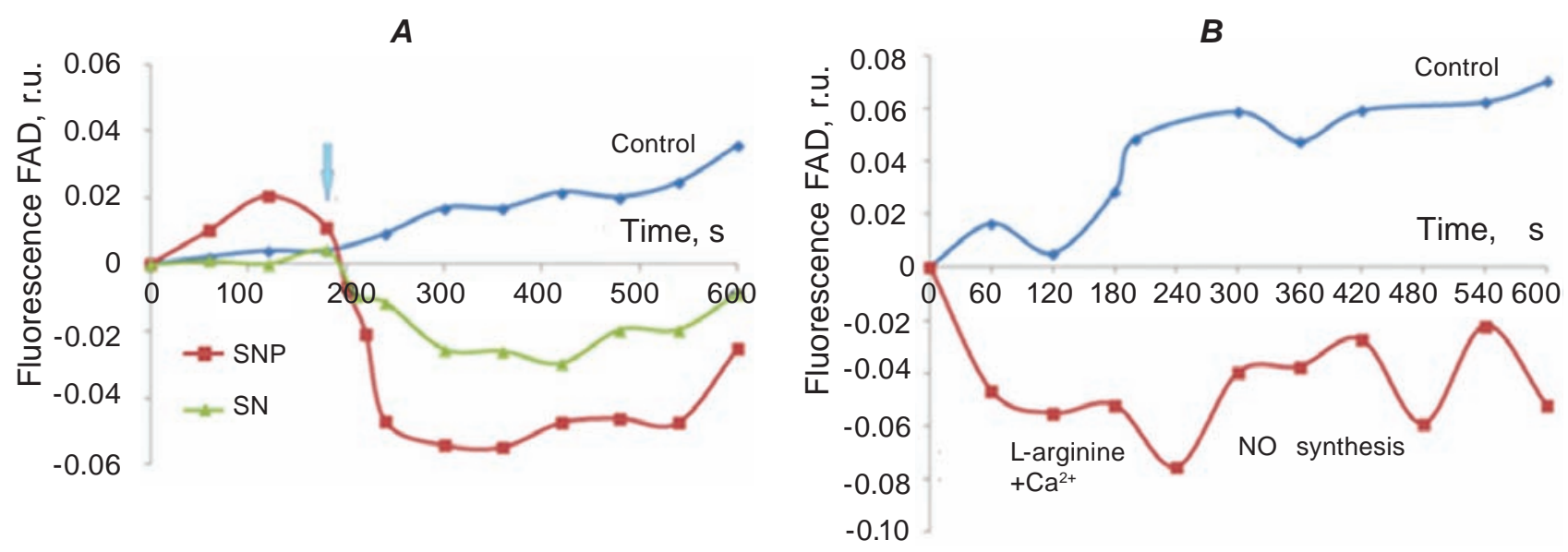

Fig. 9. Changes in FAD fluorescence in isolated mitochondria under the influence of $100 \mu M$ SNP and SN (A)

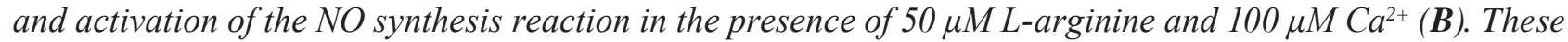
data represent typical experiments

tionship between mitochondrial function and uterine smooth muscle physiology, the role of nitric oxide and $\mathrm{Ca}^{2+}$ in these processes.

Conclusion. NO, depending on concentration and chemical microenvironment, exhibits functional activity either influencing the course of physiological processes or being involved in the development of various pathological conditions. The importance of nitric oxide in the biochemical mechanisms of utera relaxation and reduction of myometrium sensitivity to uteroconstrictor effects during pregnancy has been proven. It has been shown that NO in the uterus can be generated in endometrial tissue, vascular endothelium and nerve endings, as well as in the placenta during pregnancy. NO synthesis, mainly studied in the uterus of pregnant women and animals, is provided by eNOS and iNOS, the expression and regulation of which are under the influence of hormones. The smooth muscle contractile activity is controlled primarily by Ca ions. Their low physiologically significant concentration in the myoplasm is maintained owing to the functioning of the NO system. The role of nitric oxide in the female reproductive system as a tocolytic becomes crucial with increasing gestational age during the normal pregnancy course: NO production and sensitivity to NO decrease in late pregnancy, preceding the onset of labor.

The relaxing effect of $\mathrm{NO}$ on the myometrium is associated either with an increase in myoplasm cGMP or a direct impact of nitrosylating nitric oxide derivatives on the plasmalemma cation-transport systems. We have shown that the polarizing effect of nitric oxide in uterine myocytes is due to an increase in the $\mathrm{K}^{+}$permeability of the plasmalemma and depends on Ca ions. Thus, it could be related to the activation of $\mathrm{Ca}^{2+}$-dependent $\mathrm{K}^{+}$-channels. Local subsarcolemmal increase in the concentration of $\mathrm{Ca}^{2+}$ may occur due to temporary inhibition of PMCA by nitric oxide. The increase in plasmalemma $\mathrm{K}^{+}$permeability can act as an important $\mathrm{Ca}^{2+}$, NOdependent factor in maintaining the relative nonexcitability of the myometrium during pregnancy. The increase in the plasmalemma electric potential under the action of nitrocompounds can also be explained by the cGMP-dependent stimulation of $\mathrm{Na}^{+}, \mathrm{K}^{+}$-ATPase activity. The probable consequence of these membrane and ionic processes is a shift in the membrane potential from threshold values necessary for activating ion-transport systems and a decrease in the myoplasm $\mathrm{Ca}^{2+}$ concentration. Our results confirm the influence of nitric oxide on $\mathrm{Ca}^{2+}$ homeostasis, namely the inhibition of the mechanisms of increasing $\mathrm{Ca}$ ions in the myoplasm in the case of the action of carbachol and oxytocin on the myocytes.

Disruption of $\mathrm{Ca}^{2+}$ homeostasis and the resulting cellular pathology may be caused by disorders in $\mathrm{Ca}^{2+}$ transport systems located in mitochondria, which function as a highly efficient $\mathrm{Ca}^{2+}$ storage owing to the ability to accumulate and release significant amounts of the cation. The results of our research prove the role of the myometrium mitochondria as an important source and target of NO action. Nitric oxide is generated in mitochondria in the $\mathrm{Ca}^{2+}$-calmodulin-regulated process, the effi- 
ciency of which depends on the degree of energization. The action of nitric oxide on mitochondria is to regulate the transport of $\mathrm{Ca}^{2+}$ in the inner membrane and the processes associated with their bioenergy, namely the effect on the electric potential and oxidation of adenine nucleotides in the electron transport chain. In addition, nitric oxide has a protective effect on mitochondria.

Considering the importance of nitric oxide as a signaling and regulatory molecule for controlling the contractile function of smooth muscle, in particular the myometrium, we see prospects for further research in three fundamental areas: 1 - a study of biochemical peculiarities of NO biosynthesis in mitochondria, the final establishment of the structure and localization of mtNOS; 2 - elucidation of molecular mechanisms of nitric oxide action as a possible endogenous specific regulator of $\mathrm{Ca}^{2+}$ concentration in myocytes, functioning of $\mathrm{Ca}^{2+}$-transport systems of mitochondria and bioenergetic processes in them; 3 - search for exogenous non-toxic modulators of mitochondrial functional activity, namely their NOsynthase ability, bioenergetics and $\mathrm{Ca}^{2+}$-homeostasis in order to develop future pharmaceuticals to overcome mitochondrial dysfunction and targeted regulation of contractile activity. Systematic in vivo studies in experimental animals and female volunteers are also needed to establish nitric oxide significance in uterine tissues at different functional periods.

Conflict of interest. Authors have completed the Unified Conflicts of Interest form at http://ukrbiochemjournal.org/wp-content/uploads/2018/12/ coi_disclosure.pdf and declare no conflict of interest.

Funding. The work was conducted on budget costs of NAS of Ukraine, project N 0119U002508.

Acknowledgments. Authors thanks Academician of the NAS of Ukraine Kosterin S.O. for valuable advice and recommendations during the analysis and discussion of scientific results, as well as Ph.D. Karahim S.O. and Ph.D. Chunikhin O.Yu. for technical support of works on a laser confocal microscope and a flow cytometer.

\section{БІОХІМІЧНІ ТА МОЛЕКУЛЯРНО- ФІЗІОЛОГІЧНІ АСПЕКТИ ДІЇ ОКСИДУ АЗОТУ ЯК РЕГУЛЯТОРА ФУНКЦІОНУВАННЯ МАТКИ}

\author{
Г. В. Данилович, Ю. В. Данилович \\ Інститут біохімії ім. О. В. Палладіна \\ НАН України, Київ; \\ e-mail: danylovych@biochem.kiev.ua
}

Проаналізовано джерела утворення оксиду азоту (NO) в матці та динаміка зміни його вмісту у різні періоди функціонування органу у жінок та тварин. Розглянуті біохімічні механізми дії оксиду азоту на скоротливу активність міометрія і значення NO в фізіологічних процесах перебігу вагітності і пологах. Акцентовано увагу на значенні мітохондрій як можливого джерела NO в гладенькому м'язі і описані його можливі шляхи впливу на транспорт $\mathrm{Ca}^{2+}$ та біоенергетичні процеси у мітохондріях. Проаналізовано власні результати досліджень іонних і мембранних механізмів дії $\mathrm{NO}$ на $\mathrm{Ca}^{2+}$-гомеостаз міоцитів матки. Подано і обговорено дані авторів щодо ідентифікації оксиду азоту в мітохондріях гладенького м'яза матки, біохімічних характеристик NO-синтазної реакції та можливої ролі NO у регуляції транспорту $\mathrm{Ca}^{2+}$ в цих субклітинних структурах і функціонування електронно-транспортного ланцюга.

К л ю ч о в і с л о в а: матка, вагітність, оксид азоту, мітохондрії, кальцій.

\section{References}

1. Treuer AV, Gonzalez DR. Nitric oxide synthases, S-nitrosylation and cardiovascular health: from molecular mechanisms to therapeutic opportunities (review). Mol Med Rep. 2015; 11(3): 1555-1565.

2. Ghimire K, Altmann HM, Straub AC, Isenberg JS. Nitric oxide: what's new to NO? Am J Physiol Cell Physiol. 2017; 312(3): C254-C262.

3. Bryan NS, Bian K, Murad F. Discovery of the nitric oxide signaling pathway and targets for drug development. Front Biosci (Landmark Ed). 2009; 14: 1-18. 
4. Philippu A. Nitric Oxide: A Universal Modulator of Brain Function. Curr Med Chem. 2016; 23(24): 2643-2652.

5. Pitocco D, Zaccardi F, Di Stasio E, Romitelli F, Santini SA, Zuppi C, Ghirlanda G. Oxidative stress, nitric oxide, and diabetes. Rev Diabet Stud. 2010; 7(1): 15-25.

6. Sladek SM, Magness RR, Conrad KP. Nitric oxide and pregnancy. Am J Physiol. 1997; 272(Pt 2): R441-R463.

7. Buxton ILO. Regulation of uterine function: a biochemical conundrum in the regulation of smooth muscle relaxation. Mol Pharmacol. 2004; 65(5): 1051-1059.

8. López Bernal A. The regulation of uterine relaxation. Semin Cell Dev Biol. 2007; 18(3): 340-347.

9. Tiboni GM, Giampietro F, Lamonaca D. The soluble guanylate cyclase inhibitor methylene blue evokes preterm delivery and fetal growth restriction in a mouse model. In Vivo. 2001; 15(4): 333-337.

10. Bao S, Rai J, Schreiber J. Expression of nitric oxide synthase isoforms in human pregnant myometrium at term. $J$ Soc Gynecol Investig. 2002; 9(6): 351-356.

11. Buxton IL, Kaiser RA, Malmquist NA, Tichenor S. NO-induced relaxation of labouring and non-labouring human myometrium is not mediated by cyclic GMP. Br J Pharmacol. 2001; 134(1): 206-214.

12. Farina M, Ribeiro ML, Franchi A. Nitric oxide synthases in pregnant rat uterus. Reproduction. 2001; 121(3): 403-407.

13. Okawa T, Vedernikov YP, Saade GR, Garfield RE. Effect of nitric oxide on contractions of uterine and cervical tissues from pregnant rats. Gynecol Endocrinol. 2004; 18(4): 186-193.

14. Wray S, Prendergast C. The Myometrium: From Excitation to Contractions and Labour. In: Hashitani H., Lang R. (eds). Smooth Muscle Spontaneous Activity. Advances in Experimental Medicine and Biology. 2019; 1124.

15. Danylovych IuV, Tuhai VA. Formation of NO and $\mathrm{H}_{2} \mathrm{O}_{2}$ in endometrial stromal cells under the effect of acetylcholine. Ukr Biokhim Zhurn. 2001; 73(2): 110-115. (In Ukrainian).

16. Danylovych IuV. Effect of steroid hormones and oxytocin on $\mathrm{NO}$ and $\mathrm{H}_{2} \mathrm{O}_{2}$ production in the endometrium. Ukr Biokhim Zhurn. 2004; 76(1): 88-96. (In Ukrainian).
17. Cameron IT, Campbell S. Nitric oxide in the endometrium. Hum Reprod Update. 1998; 4(5): 565-569.

18. Khorram O, Garthwaite M, Magness RR. Endometrial and myometrial expression of nitric oxide synthase isoforms in pre- and postmenopausal women. $J$ Clin Endocrinol Metab. 1999; 84(6): 2226-2232.

19. Valdés G, Corthorn J. Review: The angiogenic and vasodilatory utero-placental network. Placenta. 2011; 32(Suppl 2): S170-S175.

20. Yellon SM, Mackler AM, Kirby MA. The role of leukocyte traffic and activation in parturition. $J$ Soc Gynecol Investig. 2003; 10(6): 323-338.

21. Zhang J, Massmann GA, Mirabile CP, Figueroa JP. Nonpregnant sheep uterine type I and type III nitric oxide synthase expression is differentially regulated by estrogen. Biol Reprod. 1999; 60(5): 1198-1203.

22. Toda N, Toda H, Okamura T. Regulation of myometrial circulation and uterine vascular tone by constitutive nitric oxide. Eur J Pharmacol. 2013; 714(1-3): 414-423.

23. Tota B, Quintieri AM, Angelone T. The emerging role of nitrite as an endogenous modulator and therapeutic agent of cardiovascular function. Curr Med Chem. 2010; 17(18): 1915-1925.

24. Ghafourifar P, Cadenas E. Mitochondrial nitric oxide synthase. Trends Pharmacol Sci. 2005; 26(4): 190-195.

25. Giulivi C, Kato K, Cooper CE. Nitric oxide regulation of mitochondrial oxygen consumption I: cellular physiology. Am J Physiol Cell Physiol. 2006; 291(6): C1225-C1231.

26. Zaobornyj T, Ghafourifar P. Strategic localization of heart mitochondrial NOS: a review of the evidence. Am J Physiol Heart Circ Physiol. 2012; 303(11): H1283-H1293.

27. Elfering SL, Sarkela TM, Giulivi C. Biochemistry of mitochondrial nitric-oxide synthase. $J$ Biol Chem. 2002; 277(41): 38079-38086.

28. Valdez LB, Zaobornyj T, Boveris A. Mitochondrial metabolic states and membrane potential modulate mtNOS activity. Biochim Biophys Acta. 2006; 1757(3): 166-172.

29. Marsh N, Marsh A. A short history of nitroglycerine and nitric oxide in pharmacology and physiology. Clin Exp Pharmacol Physiol. 2000; 27(4): 313-319.

30. Alderton WK, Cooper CE, Knowles RG. Nitric oxide synthases: structure, function and inhibition. Biochem J. 2001; 357(Pt 3): 593-615. 
31. Thomas DD, Liu X, Kantrow SP, Lancaster JR Jr. The biological lifetime of nitric oxide: implications for the perivascular dynamics of NO and $\mathrm{O}_{2}$. Proc Natl Acad Sci USA. 2001; 98(1): 355-360.

32. Levine AB, Punihaole D, Levine TB. Characterization of the role of nitric oxide and its clinical applications. Cardiology. 2012; 122(1): 55-68.

33. Zhao Y, Vanhoutte PM, Leung SWS. Vascular nitric oxide: Beyond eNOS. J Pharmacol Sci. 2015; 129(2): 83-94.

34. Reutov VP. Nitric oxide cycle in mammals and the cyclicity principle. Biochemistry (Mosc). 2002; 67(3): 293-311. (In Russian).

35. Förstermann U, Sessa WC. Nitric oxide synthases: regulation and function. Eur Heart $J$. 2012; 33(7): 829-837.

36. Andrew PJ, Mayer B. Enzymatic function of nitric oxide synthases. Cardiovasc Res. 1999; 43(3): 521-531.

37. Daff S. NO synthase: structures and mechanisms. Nitric Oxide. 2010; 23(1): 1-11.

38. Förstermann U, Closs EI, Pollock JS, Nakane M, Schwarz P, Gath I, Kleinert H. Nitric oxide synthase isozymes. Characterization, purification, molecular cloning, and functions. Hypertension. 1994; 23(6 Pt 2): 1121-1131.

39. Tsai KD, Chen W, Wang SH, Hsiao YW, Chi JY, Wu HY, Lee YJ, Wong HY, Tseng MJ, Lin TH. Downregulation of connective tissue growth factor by LPS/IFN- $\gamma$-induced nitric oxide is reversed by aristolochic acid treatment in glomerular mesangial cells via STAT- $1 \alpha$ and NF- $\kappa$ B signaling. Chem Biol Interact. 2014; 210: 86-95.

40. Siomek A. NF- $\kappa B$ signaling pathway and free radical impact. Acta Biochim Pol. 2012; 59(3): 323-331.

41. Nosarev AV, Smagliy LV, Anfinogenova Y, Popov SV, Kapilevich LV. Exercise and NO production: relevance and implications in the cardiopulmonary system. Front Cell Dev Biol. 2015; 2: 73.

42. Carreras MC, Poderoso JJ. Mitochondrial nitric oxide in the signaling of cell integrated responses. Am J Physiol Cell Physiol. 2007; 292(5): C1569-C1580.

43. Tripathi P. Nitric oxide and immune response. Indian J Biochem Biophys. 2007; 44(5): 310-319.
44. Tengan CH, Rodrigues GS, Godinho RO.Nitric oxide in skeletal muscle: role on mitochondrial biogenesis and function. Int $J$ Mol Sci. 2012; 13(12): 17160-17184.

45. Ogura T, Yokoyama T, Fujisawa H, Kurashima Y, Esumi H. Structural diversity of neuronal nitric oxide synthase mRNA in the nervous system. Biochem Biophys Res Commun. 1993; 193(3): 1014-1022.

46. Silvagno F, Xia H, Bredt DS. Neuronal nitricoxide synthase-mu, an alternatively spliced isoform expressed in differentiated skeletal muscle. J Biol Chem. 1996; 271(19): 1120411208.

47. Brenman JE, Chao DS, Gee SH, McGee AW, Craven SE, Santillano DR, Wu Z, Huang F, Xia H, Peters MF, Froehner SC, Bredt DS. Interaction of nitric oxide synthase with the postsynaptic density protein PSD-95 and alpha1syntrophin mediated by PDZ domains. Cell. 1996; 84(5): 757-767.

48. Brenman JE, Xia H, Chao DS, Black SM, Bredt DS. Regulation of neuronal nitric oxide synthase through alternative transcripts. Dev Neurosci. 1997; 19(3): 224-231.

49. Kone BC, Kuncewicz T, Zhang W, Yu ZY. Protein interactions with nitric oxide synthases: controlling the right time, the right place, and the right amount of nitric oxide. Am J Physiol Renal Physiol. 2003; 285(2): F178-F190.

50. Duan W, Zhou J, Li W, Zhou T, Chen Q, Yang F, Wei T. Plasma membrane calcium ATPase 4b inhibits nitric oxide generation through calciuminduced dynamic interaction with neuronal nitric oxide synthase. Protein Cell. 2013; 4(4): 286-298.

51. Heinonen I, Saltin B, Hellsten Y, Kalliokoski KK. The effect of nitric oxide synthase inhibition with and without inhibition of prostaglandins on blood flow in different human skeletal muscles. Eur J Appl Physiol. 2017; 117(6): 1175-1180.

52. Li Q, Chen Y, Zhang X, Zuo S, Ge H, Chen Y, Liu X, Zhang JH, Ruan H, Feng H. Scutellarin attenuates vasospasm through the Erk5-KLF2eNOS pathway after subarachnoid hemorrhage in rats. J Clin Neurosci. 2016;34:264-270.

53. Durán WN, Breslin JW, Sánchez FA. The NO cascade, eNOS location, and microvascular permeability. Cardiovasc Res. 2010; 87(2): 254261. 
54. Lee JE, Yuan H, Liang FX, Sehgal PB. Nitric oxide scavenging causes remodeling of the endoplasmic reticulum, Golgi apparatus and mitochondria in pulmonary arterial endothelial cells. Nitric Oxide. 2013; 33: 64-73.

55. Shaul PW, Smart EJ, Robinson LJ, German Z, Yuhanna IS, Ying Y, Anderson RG, Michel T. Acylation targets emdothelial nitric-oxide synthase to plasmalemmal caveolae. $\mathrm{J}$ Biol Chem. 1996; 271(11): 6518-6522.

56. Davidson SM, Duchen MR. Effects of NO on mitochondrial function in cardiomyocytes: Pathophysiological relevance. Cardiovasc Res. 2006; 1(1): 10-21.

57. Komeima K, Hayashi Y, Naito Y, Watanabe Y. Inhibition of neuronal nitric-oxide synthase by calcium/ calmodulin-dependent protein kinase IIalpha through Ser847 phosphorylation in NG108-15 neuronal cells. J Biol Chem. 2000; 275(36): 28139-28143.

58. Litvinova L, Atochin DN, Fattakhov N, Vasilenko M, Zatolokin P, Kirienkova E. Nitric oxide and mitochondria in metabolic syndrome. Front Physiol. 2015; 6: 20.

59. Franco MC, Arciuch VGA, Peralta JG, Galli S, Levisman D, López LM, Romorini L, Poderoso JJ, Carreras MC. Hypothyroid phenotype is contributed by mitochondrial complex I inactivation due to translocated neuronal nitric-oxide synthase. $J$ Biol Chem. 2006; 281(8): 4779-4786.

60. Nagano T, Fridovich I. The co-oxidation of ammonia to nitrite during the aerobic xanthine oxidase reaction. Arch Biochem Biophys. 1985; 241(2): 596-601.

61. Dull BJ, Hotchkiss JH. Activated oxygen and mammalian nitrate biosynthesis. Carcinogenesis. 1984; 5(9): 1161-1164.

62. Guerra DD, Hurt KJ. Gasotransmitters in pregnancy: from conception to uterine involution. Biol Reprod. 2019; 101(1): 4-25.

63. Omar SA, Webb AJ, Lundberg JO, Weitzber E. Therapeutic effects of inorganic nitrate and nitrite in cardiovascular and metabolic diseases. J Intern Med. 2016; 279(4): 315-336.

64. Lundberg JO, Weitzberg E, Gladwin MT. The nitrate-nitrite-nitric oxide pathway in physiology and therapeutics. Nat Rev Drug Discov. 2008; 7(2): 156-167.

65. Sybirna NO, Lyuta MYa, Klymyshyn NI. Molecular mechanisms of nitric oxide deposition in erythrocytes. Biol Stud. 2010; 4(1): 143-160. (In Ukrainian).

66. Shiva S. Mitochondria as metabolizers and targets of nitrite. Nitric Oxide. 2010; 22(2): 6474.

67. Shiva S. Nitrite: a physiological store of nitric oxide and modulator of mitochondrial function. Redox Biol. 2013; 1(1): 40-44.

68. Siervo M, Scialò F, Shannon OM, Stephan BCM, Ashor AW. Does dietary nitrate say NO to cardiovascular ageing? Current evidence and implications for research. Proc Nutr Soc. 2018; 77(2): 112-123.

69. Fernando V, Zheng X, Walia Y, Sharma V, Letson J, Furuta S. S-Nitrosylation: An Emerging Paradigm of Redox Signaling. Antioxidants (Basel). 2019; 8(9): 404.

70. Liu C, Liang MC, Soong TW. Nitric Oxide, Iron and Neurodegeneration. Front Neurosci. 2019; 13: 114.

71. Kleschyov AL. The NO-heme signaling hypothesis. Free Radic Biol Med. 2017; 112: 544-552.

72. Corbin JD. Mechanisms of action of PDE5 inhibition in erectile dysfunction. Int $J$ Impot Res. 2004; 16(Suppl 1): S4-S7.

73. Leite ACR, Oliveira HCF, Utino FL, Garcia R, Alberici LC, Fernandes MP, Castilho RF, Vercesi AE. Mitochondria generated nitric oxide protects against permeability transition via formation of membrane protein S-nitrosothiols. Biochim Biophys Acta. 2010; 1797(6-7): 12101216.

74. Ulrich C, Quilici DR, Schlauch KA, Buxton ILO. The human uterine smooth muscle S-nitrosoproteome fingerprint in pregnancy, labor, and preterm labor. Am J Physiol Cell Physiol. 2013; 305(8): C803-C816.

75. Garfield RE, Saade G, Buhimsch C, Buhimschi I, Shi L, Shi SQ, Chwalisz K. Control and assessment of the uterus and cervix during pregnancy and labour. Hum Reprod Update. 1998; 4(5): 673-695.

76. Bulbul A, Yağci A, Altunbaş K, Sevimli A, Celik HA, Karadeniz A, Akdağ E. The role of nitric oxide in the effects of ovarian steroids on spontaneous myometrial contractility in rats. Theriogenology. 2007; 68(8): 1156-1168.

77. Ravanos K, Dagklis T, Petousis S, MargioulaSiarkou C, Prapas Y, Prapas N. Factors implicated in the initiation of human parturition 
in term and preterm labor: a review. Gynecol Endocrinol. 2015; 31(9): 679-683.

78. Aguilar HN, Mitchell BF. Physiological pathways and molecular mechanisms regulating uterine contractility. Hum Reprod Update. 2010; 16(6): 725-744.

79. Nadeem L, Shynlova O, Mesiano S, Lye S. Progesterone Via its Type-A Receptor Promotes Myometrial Gap Junction Coupling. Sci Rep. 2017; 7(1): 13357.

80. Mitchell BF, Aguilar HN, Mosher A, Wood S, Slater DM. The uterine myocyte as a target for prevention of preterm birth. Facts Views Vis Obgyn. 2013; 5(1): 72-81.

81. Chalmers S, Olson ML, MacMillan D, Rainbow RD, McCarron JG. Ion channels in smooth muscle: regulation by the sarcoplasmic reticulum and mitochondria. Cell Calcium. 2007; 42(4-5): 447-466.

82. Trebak M, Ginnan R, Singer HA, Jourd'heuil D. Interplay between calcium and reactive oxygen/ nitrogen species: an essential paradigm for vascular smooth muscle signaling. Antioxid Redox Signal. 2010; 12(5): 657-674.

83. Aguilar HN, Tracey CN, Zielnik B, Mitchell BF. Rho-kinase mediates diphosphorylation of myosin regulatory light chain in cultured uterine, but not vascular smooth muscle cells. $J$ Cell Mol Med. 2012; 16(12): 2978-2989.

84. Smeazzetto S, Armanious GP, Moncelli MR, Bak JJ, Lemieux MJ, Young HS, TadiniBuoninsegni F. Conformational memory in the association of the transmembrane protein phospholamban with the sarcoplasmic reticulum calcium pump SERCA. J Biol Chem. 2017; 292(52): 21330-21339.

85. Tarasova NV, Vishnyakova PA, Logashina YA, Elchaninov AV. Mitochondrial calcium uniporter structure and function in different types of muscle tissues in health and disease. Int $J \mathrm{Mol}$ Sci. 2019; 20(19): 4823.

86. Malli R, Graier WF. Mitochondrial $\mathrm{Ca}^{2+}$ channels: Great unknowns with important functions. FEBS Lett. 2010; 584(10): 1942-1947.

87. Norman JE, Cameron IT. Nitric oxide in the human uterus. Rev Reprod. 1996; 1(1): 61-68.

88. Zullino S, Buzzella F , Simoncini T. Nitric oxide and the biology of pregnancy. Vascul Pharmacol. 2018; 110: 71-74.

89. Xiao D, Pearce WJ, Zhang L. Pregnancy enhances endothelium-dependent relaxation of ovine uterine artery: role of $\mathrm{NO}$ and intracellular $\mathrm{Ca}^{2+}$. Am J Physiol Heart Circ Physiol. 2001; 281(1): H183-H190.

90. Danylovych IuV. Mechanisms of acetylcholinedependent production of $\mathrm{H}_{2} \mathrm{O}_{2}$ and $\mathrm{NO}_{2}^{-}$by stromal cells of endometrium. Ukr Biokhim Zhurn. 2003; 75(5): 77-84. (In Ukrainian).

91. Arthur P, Taggart MJ, Zielnik B, Wong S, Mitchell BF. Relationship between gene expression and function of uterotonic systems in the rat during gestation, uterine activation and both term and preterm labour. J Physiol. 2008; 586(24): 6063-6076.

92. Li Y, Zhou X, Wei QW, Huang RH, Shi FX. Cellspecific expression and immunolocalization of nitric oxide synthase isoforms and soluble guanylyl cyclase $\alpha$ and $\beta$ subunits in postnatal porcine uteri. Acta Histochem. 2014; 116(3): 466-473.

93. Buhimschi IA, Saade GR, Chwalisz K, Garfield RE. The nitric oxide pathway in preeclampsia: pathophysiological implications. Hum Reprod Update. 1998; 4(1): 25-42.

94. Tiboni GM, Corso AD, Marotta F. Progestational agents prevent preterm birth induced by a nitric oxide synthesis inhibitor in the mouse. In Vivo. 2008; 22(4): 447-450.

95. Rytlewski K, Olszanecki R, Lauterbach R, Grzyb A, Kiec-Wilk B, Dembinska-Kiec A, Basta A. Effects of oral L-arginine on the pulsatility indices of umbilical artery and middle cerebral artery in preterm labor. Eur J Obstet Gynecol Reprod Biol. 2008; 138(1): 23-28.

96. Aljameil $\mathrm{N}$, Tabassum $\mathrm{H}$, AlMayouf $\mathrm{H}$, Alshenefy A, Almohizea MM, Ali M N. Identification of serum cytokines as markers in women with recurrent pregnancy loss or miscarriage using MILLIPLEX analysis. Biomed Res. 2018; 29(18): 3512-3517.

97. Javadi-Paydar M, Lesani A, Vakilipour R, Ghazi P, Tavangar SM, Hantoushzadeh S, Norouzi A, Dehpour AR. Evaluation of the tocolytic effect of morphine in a mouse model of lipopolysaccharide-induced preterm delivery: the role of nitric oxide. Eur J Obstet Gynecol Reprod Biol. 2009; 147(2): 166-172.

98. Ramesh S, Morrell CN, Tarango C, Thomas GD, Yuhanna IS, Girardi G, Herz J, Urbanus RT, de Groot PG, Thorpe PE, Salmon JE, Shaul PW, Mineo C. Antiphospholipid antibodies promote leukocyte-endothelial cell adhesion and 
thrombosis in mice by antagonizing eNOS via B2GPI and apoER2. J Clin Invest. 2011; 121(1): 120-131.

99. Miranda S, Billoir P, Damian L, Thiebaut PA, Schapman D, Le Besnerais M, Jouen F, Galas L, Levesque H, Le Cam-Duchez V, Joannides R, Richard V, Benhamou Y. Hydroxychloroquine reverses the prothrombotic state in a mouse model of antiphospholipid syndrome: Role of reduced inflammation and endothelial dysfunction. PLoS One. 2019; 14(3): e0212614.

100. Buttery LD, McCarthy A, Springall DR, Sullivan MH, Elder MG, Michel T, Polak JM. Endothelial nitric oxide synthase in the human placenta: regional distribution and proposed regulatory role at the feto-maternal interface. Placenta. 1994; 15(3): 257-265.

101. Norman J. Nitric oxide and the myometrium. Pharmacol Ther. 1996; 70(2): 91-100.

102. Bradley KK, Buxton IL, Barber JE, McGaw T, Bradley ME. Nitric oxide relaxes human myometrium by a cGMP-independent mechanism. Am J Physiol. 1998; 275(6): C1668-C1673.

103. Buhimschi I, Yallampalli C, Dong YL, Garfield RE. Involvement of a nitric oxidecyclic guanosine monophosphate pathway in control of human uterine contractility during pregnancy. Am J Obstet Gynecol. 1995; 172(5): 1577-1584.

104. Hennan JK, Diamond J. Evidence that spontaneous contractile activity in the rat myometrium is not inhibited by NO-mediated increases in tissue levels of cyclic GMP. $\mathrm{Br} J$ Pharmacol. 1998; 123(5): 959-967.

105. Izumi H, Garfield RE. Relaxant effects of nitric oxide and cyclic GMP on pregnant rat uterine longitudinal smooth muscle. Eur J Obstet Gynecol Reprod Biol. 1995; 60(2): 171-180.

106. Syal AS, Vedernikov YP, Chwalisz K, Saade GR, Garfield RE. Both soluble guanylate cyclase and particulate guanylate cyclase regulate myometrial contractility. Am J Obstet Gynecol. 1998; 179(1): 111-116.

107. Vedernikov YP, Syal AS, Okawa T, Jain V, Saade GR, Garfield RE. The role of cyclic nucleotides in the spontaneous contractility and responsiveness to nitric oxide of the rat uterus at midgestation and term. Am J Obstet Gynecol. 2000; 182(3): 612-619.

108. Poniedziałek-Czajkowska E, Marciniak B, Kimber-Trojnar Z, Leszczyńska-Gorzelak B,
Oleszczuk J. Nitric oxide in normal and preeclamptic pregnancy. Curr Pharm Biotechnol. 2011; 12(5): 743-749.

109. Yallampalli C, Izumi H, Byam-Smith $M$, Garfield RE. An L-arginine-nitric oxidecyclic guanosine monophosphate system exists in the uterus and inhibits contractility during pregnancy. Am J Obstet Gynecol. 1994; 170(Pt 1): 175-185.

110. Demirkoprulu N, Cetin M, Bagcivan I, Kaya T, Soydan AS, Karadas B, Cetin A. Comparative relaxant effects of $\mathrm{YC}-1$ and DETA/NO on spontaneous contractions and the levels of cGMP of isolated pregnant rat myometrium. Eur J Pharmacol. 2005; 517(3): 240-245.

111. Mirabile CPJr, Massmann GA, Figueroa JP. Physiologic role of nitric oxide in the maintenance of uterine quiescence in nonpregnant and pregnant sheep. Am J Obstet Gynecol. 2000; 183(1): 191-198.

112. Wetzka B, Schäfer WR, Stehmans A, Zahradnik HP. Effects of nitric oxide donors on the contractility and prostaglandin synthesis of myometrial strips from pregnant and nonpregnant women. Gynecol Endocrinol. 2001; 15(1): 34-42.

113. Buhimschi I, Ali M, Jain V, Chwalisz K, Garfield RE. Differential regulation of nitric oxide in the rat uterus and cervix during pregnancy and labour. Hum Reprod. 1996; 11(8): 1755-1766.

114. Kuenzli KA, Bradley ME, Buxton IL. Cyclic GMP-independent effects of nitric oxide on guinea-pig uterine contractility. $\mathrm{Br} \quad \mathrm{J}$ Pharmacol. 1996; 119(4): 737-743.

115. Hoffmann P, Stanke-Labesque F, Fanchin R, Dilai N, Pons JC, Ayoubi JM. Effects of L-arginine and sodium nitroprusside on the spontaneous contractility of human nonpregnant uterus. Hum Reprod. 2003; 18(1): 148-151.

116. Pucovský V, Gordienko DV, Bolton TB. Effect of nitric oxide donors and noradrenaline on $\mathrm{Ca}^{2+}$ release sites and global intracellular $\mathrm{Ca}^{2+}$ in myocytes from guinea-pig small mesenteric arteries. J Physiol. 2002; 539(Pt 1): 25-39.

117. Barnett SD, Smith CR, Ulrich CC, Baker JE, Buxton ILO. S-Nitrosoglutathione Reductase Underlies the Dysfunctional Relaxation to Nitric Oxide in Preterm Labor. Sci Rep. 2018; 8(1): 5614. 
118. Conde-Agudelo A, Romero R. Transdermal nitroglycerin for the treatment of preterm labor: a systematic review and metaanalysis. $A m$ J Obstet Gynecol. 2013; 209(6): 551.e1-551.e18.

119. Zhou XB, Wang GX, Ruth P, Hüneke B, Korth M. $\mathrm{BK}(\mathrm{Ca})$ channel activation by membraneassociated cGMP kinase may contribute to uterine quiescence in pregnancy. Am $J$ Physiol Cell Physiol. 2000; 279(6): C1751-C1759.

120. Shimano M, Nakaya Y, Fukui R, Kamada M, Hamada Y, Maeda K, Aono T. Activation of $\mathrm{Ca}^{2+}$-activated $\mathrm{K}^{+}$channels in human myometrium by nitric oxide. Gynecol Obstet Invest. 2000; 49(4): 249-254.

121. Tsymbalyuk O V, Kosterin S O. Influence of calixarene C-90 on contractile activity of rat myometrium smooth muscles. Biol Stud. 2013; 7(3): 5-20.

122. Okawa T, Sato A, Syal AS, Vedernikov YP, Saade GR, Garfield RE. Effects of nitric oxide donors on non-pregnant and pregnant rat uterine and aortic smooth muscle. Fukushima J Med Sci. 2003; 49(1): 23-32.

123. Tribe RM. Regulation of human myometrial contractility during pregnancy and labour: are calcium homeostatic pathways important? Exp Physiol. 2001; 86(2): 247-254.

124. Danylovych YuV. Nitric oxide as the regulator of intracellular homeostasis in the uterus myocytes. Ukr Biokhim Zhurn. 2012; 84(3): 5-25. (In Ukrainian).

125. Danylovych HV, Danylovych YuV, Kosterin SO. Nitric oxide induced polarization of myometrium cells plasmalemma revealed by application of fluorescent dye 3,3'-dihexyloxacarbocyanine. Ind $J$ Biochem Biophys. 2019; 55: 34-45.

126. Danylovych YuV. Characteristics of passive $\mathrm{Ca}^{2+}$-transport from cells of the myometrium sarcoplasmic reticulum in rats. Fiziol $Z$ h. 2007; 53(1): 55-61. (In Ukrainia).

127. Ghafourifar P, Richter C. Nitric oxide synthase activity in mitochondria. FEBS Lett. 1997; 418(3): 291-296.

128. Dedkova EN, Blatter LA. Characteristics and function of cardiac mitochondrial nitric oxide synthase. J Physiol. 2009; 587(Pt 4): 851-872.

129. Tatoyan A, Giulivi C. Purification and characterization of a nitric-oxide synthase from rat liver mitochondria. J Biol Chem. 1998; 273(18): 11044-11048.
130. Parihar MS, Nazarewicz RR, Kincaid E, Bringold U, Ghafourifar P. Association of mitochondrial nitric oxide synthase activity with respiratory chain complex I. Biochem Biophys Res Commun. 2008; 366(1): 23-28.

131. Danylovych HV, Danylovych YuV, Gulina MO, Bohach TV, Kosterin SO. NO-synthase activity in mitochondria of uterus smooth muscle: identification and biochemical properties. Gen Physiol Biophys. 2019; 38(1): 39-50.

132. Valdez LB, Boveris A. Mitochondrial nitric oxide synthase, a voltage-dependent enzyme, is responsible for nitric oxide diffusion to cytosol. Front Biosci. 2007; 12: 1210-1219.

133. Bustamante J, Bersier G, Badin RA, Cymeryng C, Parodi A, Boveris A. Sequential NO production by mitochondria and endoplasmic reticulum during induced apoptosis. Nitric Oxide. 2002; 6(3): 333-341.

134. Boveris A, Valdez LB, Alvarez S, Zaobornyj T, Boveris AD, Navarro A. Kidney mitochondrial nitric oxide synthase. Antioxid Redox Signal. 2003; 5(3): 265-271.

135. Lores-Arnaiz S, D'Amico G, Czerniczyniec A, Bustamante J, Boveris A. Brain mitochondrial nitric oxide synthase: in vitro and in vivo inhibition by chlorpromazine. Arch Biochem Biophys. 2004; 430(2): 170-177.

136. Alvarez S, Boveris A. Mitochondrial nitric oxide metabolism in rat muscle during endotoxemia. Free Radic Biol Med. 2004; 37(9): 1472-1478.

137. Danylovych YuV, Karakhim SA, Kolomiets OV, Danylovych GV, Kosterin SO. Identification of nitric oxide in mitochondria of myometrium cell. Biopolym Cell. 2015; 31(3): 174-178.

138. Danylovych HV, Danylovych YuV, Bohach TV, Hurska VT, Kosterin SO. Sources and regulation of nitric oxide synthesis in uterus smooth muscle cells. Ukr Biochem J. 2019; 1(4): 33-40.

139. Santo-Domingo J, Demaurex N. Calcium uptake mechanisms of mitochondria. Biochim Biophys Acta. 2010; 1797(6-7): 907-912.

140. Takeuchi A, Kim B, Matsuoka S.The destiny of $\mathrm{Ca}^{2+}$ released by mitochondria. J Physiol Sci. 2015; 65(1): 11-24.

141. Gellerich FN, Gizatullina Z, Trumbeckaite S, Nguyen HP, Pallas T, Arandarcikaite O, Vielhaber S, Seppet E, Striggow F. The regulation of OXPHOS by extramitochondrial calcium. Biochim Biophys Acta. 2010; 1797(6-7): 1018-1027. 
142. Traaseth N, Elfering S, Solien J, Haynes V, Giulivi C. Role of calcium signaling in the activation of mitochondrial nitric oxide synthase and citric acid cycle. Biochim Biophys Acta. 2004; 1658(1-2): 64-71.

143. Bernardi P, von Stockum S. The permeability transition pore as a $\mathrm{Ca}^{2+}$ release channel: new answers to an old question. Cell Calcium. 2012; 52(1): 22-27.

144. Anderson AJ, Jackson TD, Stroud DA, Stojanovski D. Mitochondria-hubs for regulating cellular biochemistry: emerging concepts and networks. Open Biol. 2019; 9(8): 190126.

145. DanylovychYuV,KarakhimSA, DanylovychHV, Kolomiets OV, Kosterin SO. Electrochemical potential of the inner mitochondrial membrane and $\mathrm{Ca}^{2+}$ homeostasis of myometrium cells. Ukr Biochem J. 2015; 87(5): 61-71.

146. Giulivi C. Mitochondria as generators and targets of nitric oxide. Novartis Found Symp. 2007; 287: 92-104.

147. Santos CXC, Anilkumar N, Zhang M, Brewer AC, Shah AM. Redox signaling in cardiac myocytes. Free Radic Biol Med. 2011; 50(7): 777-793.

148. Liu Z, Khalil RA. Evolving mechanisms of vascular smooth muscle contraction highlight key targets in vascular disease. Biochem Pharmacol. 2018; 153: 91-122.

149. Piantadosi CA, Suliman HB. Redox regulation of mitochondrial biogenesis. Free Radic Biol Med. 2012; 53(11): 2043-2053.

150. Talib J, Kwan J, Rahmanto AS, Witting PK, Davies MJ. The smoking-associated oxidant hypothiocyanous acid induces endothelial nitric oxide synthase dysfunction. Biochem $J$. 2014; 457(1): 89-97.

151. Radi R, Cassina A, Hodara R. Nitric oxide and peroxynitrite interactions with mitochondria. Biol Chem. 2002; 383(3-4): 401-409.

152. De Palma C, Clementi E. Nitric Oxide in the Regulation of Mitochondrial Biogenesis. In: Mitochondrial signaling in health and disease. Ed. S. Orrenius, L. Packer, E. Cadenas. 2012: 157-167.

153. Sanchez-Padilla J, Guzman JN, Ilijic E, Kondapalli J, Galtieri DJ, Yang B, Schieber S,
Oertel W, Wokosin D, Schumacker PT, Surmeier DJ. Mitochondrial oxidant stress in locus coeruleus is regulated by activity and nitric oxide synthase. Nat Neurosci. 2014; 17(6): 832-840.

154. Kosterin SO. Calcium transport in smooth muscles. K.: Nauk. Dumka, 1990. 216 p. (In Russian).

155. Veklich TO, Kosterin SO, Shynlova OP. Cationic specificity of a $\mathrm{Ca}^{2+}$-accumulating system in smooth muscle cell mitochondria. Ukr Biokhim Zhurn. 2002; 74(1): 42-48. (In Ukrainian).

156. Danylovych YuV, Kolomiets OV, Danylovych GV, Kosterin SO. Nitric oxide as possible regulator of energy-dependent $\mathrm{Ca}^{2+}$ transport in mitochondria of uterine smooth muscle. Int J Phys Pathophys. 2015; 6(2): 91-98.

157. Kolomiets OV, Danylovych YuV, Danylovych $\mathrm{GV} . \mathrm{H}^{+}-\mathrm{Ca}^{2+}$ exchanger in the myometrium mitochondria: modulation by exogenous and endogenous compounds. Int $J$ Phys Pathophys. 2015; 6(4): 287-297.

158. Nowikovsky $\mathrm{K}$, Pozzan $\mathrm{T}$, Rizzuto R, Scorrano L, Bernardi P. Perspectives on: SGP symposium on mitochondrial physiology and medicine: the pathophysiology of LETM1. $J$ Gen Physiol. 2012; 139(6): 445-454.

159. Danylovych IuV, Danylovych HV, Kolomiets OV, Kosterin SO, Karakhim SO, Chunikhin IuO. Investigation of nitrosactive compounds influence on polarization of the mitochondrial inner membrane in the rat uterus myocytes using potential sensitive fluorescent probe $\mathrm{DiOC}_{6}$ (3). Ukr Biochem J. 2014; 86(1): 42-55. (In Ukrainian).

160. Danylovych H, Chunikhin A, Danylovych Yu, Kosterin S. Methodology of Petri networks for simultaneous evaluation of the impact of different modifiers on the fluorescence of nucleotides from electron transport chain in isolated mitochondria and on the process of swelling. BioTechnologia. 2018; 99(1): 37-48.

161. Danylovych YuV, Chunikhin AY, Danylovych GV, Kolomiets OV. The use of the Petri net method in the simulation modeling of mitochondrial swelling. Ukr Biochem J. 2016; 88(4): 66-74. 